Check for updates

Cite this: RSC Adv., 2020, 10, 12626

Received 22nd January 2020

Accepted 6th March 2020

DOI: 10.1039/d0ra00701c

rsc.li/rsc-advances

\section{Recent advancements in synthetic methodologies of 3-substituted phthalides and their application in the total synthesis of biologically active natural products}

\author{
Amardeep Awasthi, ${ }^{a}$ Mandeep Singh, (DD a Garima Rathee (D) a \\ and Ramesh Chandra (D)*ab
}

\begin{abstract}
We have provided a critical review that focuses on key developments in the area of 3-substituted phthalides and their role in the development of important biologically active natural products. 3-Substituted phthalides are vital molecules owing to their fascinating biological activity. The scope, isolation, and characterization of various naturally occurring racemic and chiral 3-substituted phthalides have been covered. We have put significant emphasis on recently developed research methodologies for the synthesis of racemic and chiral 3-substituted phthalides. These newer approaches are essential for the development of newer and elegant strategies for the synthesis of phthalide-based or similar molecular architecture with broader substrate scope and higher stereoselectivities. Also, we have discussed the application of 3-substituted phthalides as a precursor for the synthesis of natural products and their analogs.
\end{abstract}

\section{Introduction}

One of the prime areas of research in organic chemistry has been concerned with the development of small-molecule natural products. A considerable number of modern-day drug developments are inspired by various sets of natural products, such as amino acids, flavonoids, alkaloids, terpenoids, quinonoid, and steroids. ${ }^{1}$ This area of research has paved the way for an important class of chemistry, known as medicinal chemistry.

An extensive series of biologically important natural products consist of phthalide frameworks. ${ }^{2}$ Phthalides are a prominent branch of natural products due to their biological
${ }^{a}$ Drug Discovery and Development Laboratory, Department of Chemistry, University of Delhi, Delhi-110007, India. E-mail: rameshchandragroup@gmail.com; acbrdu@ hotmail.com
${ }^{b}$ Dr. B. R. Ambedkar Center for Biomedical Research, University of Delhi, Delhi110007, India

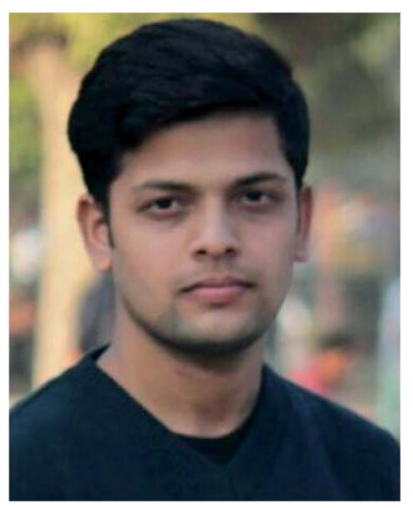

Amardeep Awasthi is a Ph.D. research scholar enrolled in the Department of Chemistry, University of Delhi, India. He obtained his M.Sc. from Visvesvaraya National Institute of Technology, Nagpur. Currently, he is pursuing his Ph.D. under the supervision of Prof. Ramesh Chandra at the Department of Chemistry, University of Delhi, India. His research interest focuses on the chemical synthesis of biologically active natural products. His Ph.D. studies are funded by DST-Inspire.

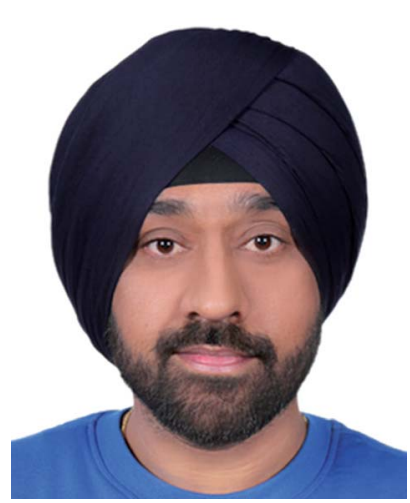

Dr Mandeep Singh is a Dr D. S. Kothari Post-doctoral fellow from 2017 in the Department of Chemistry, University of Delhi, India. He obtained his Ph.D. degree on the topic "Selective Carbon-Carbon Coupling Reactions of Phthalides" from National Chemical Laboratory, Pune, with Dr N. P. Argade in 2013. Then, he moved to Technion-Israel Institute Technology, Haifa, Israel, with Prof. Ehud Keinan to work on host-guest chemistry from 2013-2015. He worked as a research scientist in TEVA API India Pvt. Ltd., Greater Noida, from 2015-2016. His areas of expertise are organic synthesis, supramolecular chemistry, asymmetric synthesis. 
<smiles>[R][R3]1oc(=O)c2ccccc12</smiles>

$\mathrm{R}_{1}=\mathrm{H}, \mathrm{OH}, \mathrm{OMe}$, alkyl, halogen $\mathrm{R}_{2}=\mathrm{H}$, alkyl, aryl

Fig. 1 1(3H)-Isobenzofuranones 1 (phthalides) and their derivatives.

importance. The fundamental core structure of phthalide consists of a benzene ring fused with a $\gamma$-lactone between carbons 1 and 3 (Fig. 1). All the known phthalide compounds have been recognized as derivatives of $1(3 H)$-isobenzofuranone. Mainly, phthalides have been found commonly in plant genera and also in fungi, bacteria, and liverworts.

More than 180 naturally occurring phthalide derivatives have been identified. Among them, nearly 140 phthalides were isolated from a wide variety of plant species. These isolated phthalides have shown a broad spectrum of important clinical properties, such as anti-platelet accumulation, anti-smooth proliferation, anti-thrombosis, protection against cerebral ischemia, anti-angina, and cardiac function modulation and actions on the central nervous system. ${ }^{3}$

In ancient times, many phthalide-containing plants were used as herbal medicines. In China, phthalide-containing herbs have been recognized as some of the most commonly used natural medicines in traditional medicinal practice. Rhizoma Chuanxiong (Chinese name Chuanxiong) and Radix Angelicae sinensis (Chinese name Danggui) have been used for the<smiles>COc1c(C)c2c(c(O)c1C/C=C(\C)CCC(=O)O)C(=O)OC2</smiles><smiles>CCCCC1OC(=O)c2ccccc21</smiles>

Mycophenolic acid 2

Fig. 2 Structure of mycophenolic acid 2 and 3-n-butylphthalide 3.

treatment of cerebral- and cardiovascular diseases and female irregular menstruation for more than 2000 years. ${ }^{4}$

Phthalide containing drugs have gained worldwide popularity because of the wide range of pharmacophore activities of the moiety. ${ }^{5}$ For example, a significant problem during organ transplantation is a rejection of the transplanted organ. Mycophenolic acid (mycophenolate) $\mathbf{2}$ is a phthalide-containing immunosuppressant drug given to facilitate organ transplantation. It was the first antibiotic synthesized in a pure crystalline state. The US Food and Drug Administration has also approved this for use in kidney transplantation. ${ }^{6}$ Similarly, $n$ butylphthalide (NBP) 3 also became a successful anti-platelet drug for ischemia-cerebral apoplexy ${ }^{7}$ (Fig. 2). The Chinese government had approved this as an anti-ischemic stroke drug in 2002. Taking these facts into consideration, we can state that phthalide moiety has been used as a valuable framework in synthesizing many pharmaceutical drugs. ${ }^{5}$

Some phthalide-containing natural products are also reported in the literature. Phthalide plays a vital role as a building block $^{8}$ in the synthesis of many natural products. For example, fuscinarin 4 is a potent human CCR5 antagonist, used to block the entry of HIV into host cells. ${ }^{9}$ However, the bioactivities of

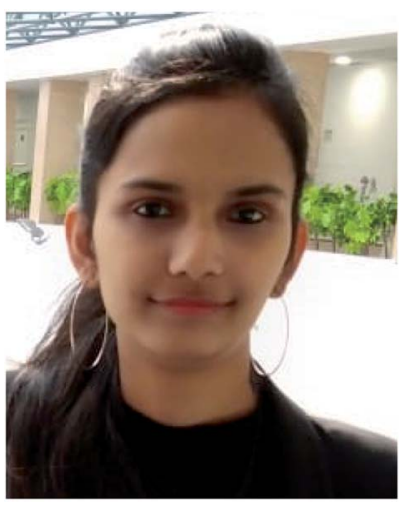

Garima Rathee obtained her M.Sc. from the University of Delhi in 2016 and BSc. from the University of Delhi in 2016. Currently, she is pursuing her Ph.D. under the supervision of Prof. Ramesh Chandra since 2016 at the Department of Chemistry, University of Delhi, India. Her research interests mainly focus on the synthesis of novel environment-friendly materials for water remediation and applications in organic methodology. Her Ph.D. studies are funded by the Department of Chemistry, University of Delhi.

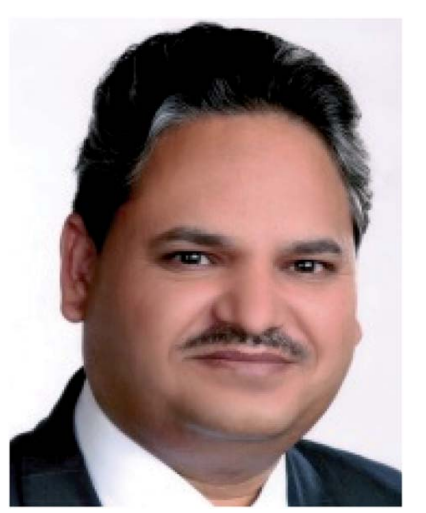

Prof. Ramesh Chandra (FRSC) is currently Head, Department of Chemistry, University of Delhi and Founder Director, Dr. B. R. Ambedkar Center for Biomedical Research (ACBR) he has been Vice-Chancellor, Bundelkhand University, Jhansi for six years (1999-2005), \& President, Indian Chemical Society, Kolkata (2004-2006). He started his research career at University of Delhi, thereafter he went to the New York Hospital-Cornell University Medical Center and The Rockefeller University; Stony brook, New York as Assistant Research Professor. He conducted advanced research at the Harvard University, Massachusetts General Hospital \& MIT, Cambridge. He has published 322 scientific Research Papers in International journals of repute and authored several books. His areas of expertise are Organic synthesis, Chemistry-Biology Interface, Catalysis, and Drug Discovery \& Development. 


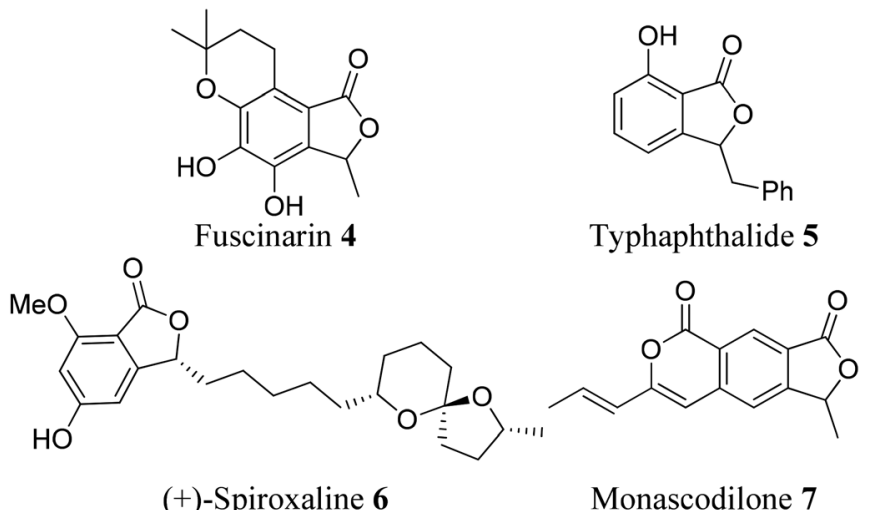

Fig. 3 Naturally occurring 1(3H)-isobenzofuranones 4-7.

(-)-typhaphthalide $\mathbf{5 , { } ^ { 1 0 }}(+)$-spiroxaline $\mathbf{6},{ }^{11}$ and monascodilone $7^{12}$ are still not known (Fig. 3).

There are several available reactive sites of phthalides which have been explored, i.e., a nucleophilic attack on $\mathrm{C}_{1}$ carbonyl group, nucleophilic substitution reactions at $\mathrm{C}_{3}$ position carbanion, and reactions on the $\mathrm{C}_{4}, \mathrm{C}_{5}, \mathrm{C}_{6}$ and $\mathrm{C}_{7}$ positions of the phthalide. ${ }^{13}$ The $1(3 H)$-isobenzofuranone was initially synthesized in 1922 by Perkin and coworkers, via thermal decomposition of ethyl 2-(bromomethyl)benzoate. ${ }^{14}$ Later in 1955, Eliel and coworkers performed the reduction of methyl phthalate to phthalide in good yield using $\mathrm{LiAlH}_{4} \cdot{ }^{15}$ In 1989, Watanabe and coworkers utilized a Diels-Alder reaction between substituted furanones and silyloxydienes to provide substituted phthalides in moderate to excellent yields. ${ }^{16}$ Recently, directed ortho-metallation, the reaction between homophthalic anhydride and benzil,${ }^{17}$ the Heck-Matsuda reaction, ${ }^{18}$ and many more methods have been introduced to synthesize substituted phthalides.

\subsection{Scope for 3-substituted phthalides}

As we have already discussed, phthalide moiety is present in many natural products. Phthalides that are substituted at the C3 positions possess an extensive range of biological and physiological activities. ${ }^{19}$ This moiety has been an essential intermediate to synthesize versatile natural products. ${ }^{20}$ This fact has led extensive efforts in the field of 3-substituted phthalides in the past two decades ${ }^{18}$ (Fig. 4). Different synthetic methodologies of selected natural products using 3-substituted phthalides as intermediates are described in the later part of the review.

Statistically, more than $60 \%$ of the drugs currently available on the market are chiral molecules. As a result, asymmetric synthesis of chiral phthalides introducing C-3 chirality has also achieved considerable attention. ${ }^{21}$ Subsequently, an extensive number of asymmetric synthetic methodologies have been established for a variety of naturally occurring molecules with the potential treatment of different kinds of diseases.

The attention of this review is primarily on the synthesis and reactivity of the active methylene compounds, i.e., 1(3H)-isobenzofuranones. Previously, Mal et al. and Renoux et al. published two excellent reviews on the chemistry of phthalides. ${ }^{5,19}$

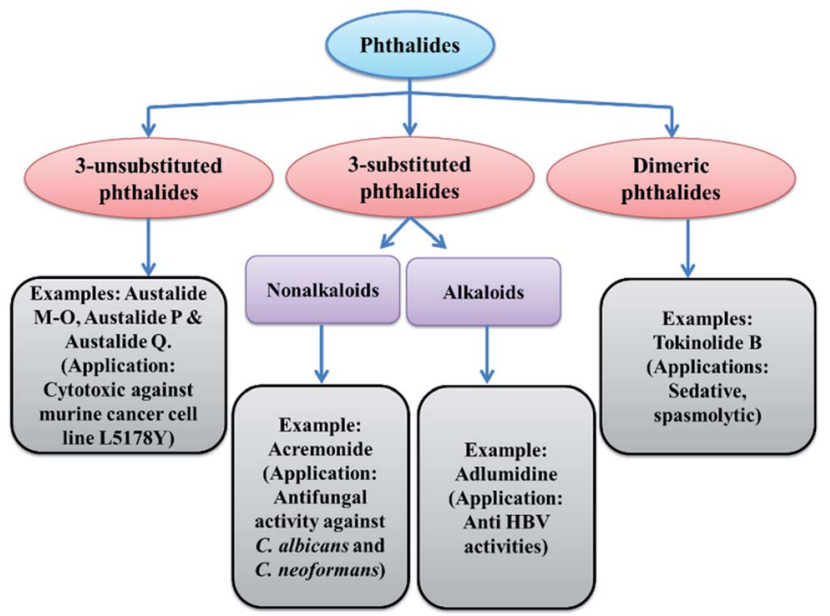

Fig. 4 Classification of phthalides and their examples.

However, as per our knowledge, in previous literature reviews, the chemistry of racemic and chiral 3 -substituted $1(3 H)$-isobenzofuranones and its application in total synthesis of important natural products was not discussed in detail. In this review, the synthetic methodologies for racemic and chiral 3substituted 1(3H)-isobenzofuranones are discussed with particular emphasis on recent advances. Also, the application of racemic and chiral 3-substituted 1(3H)-isobenzofuranones as precursors for the synthesis of other critical molecular moieties are discussed.

The work presented here can benefit researchers in developing newer efficient strategies. This review paper contributes to ongoing efforts in seeking to develop and expand the utility of 3-substituted phthalides as precursors for much broader objectives.

\subsection{Sources of a different kind of phthalides}

Plants, fungi, bacteria, and liverworts have been different sources for phthalides. More than 180 naturally occurring phthalides appear in the literature. Most of these ( 137) are extracted from 202 diverse species of plants; as a result, phthalide-containing plants were long used as herbal medicines. ${ }^{22}$ Most naturally occurring phthalides are obtained from two plant species, Ligusticum and Angelica, in the Umbelliferae family. Some of the isoquinoline type phthalides such as noscapine $\mathbf{8}$ and bicuculine $\mathbf{4 8}$ are isolated from the poppy family. From the genus Ligusticum, more than 53 naturally occurring phthalides have been isolated from Ligusticum, and 38 biologically phthalides have been isolated from Angelica. ${ }^{20,23}$

\subsection{Extraction, isolation, and characterizations of phthalides}

The extraction of naturally occurring biologically active phthalides is one of the critical steps of analysis. It involves techniques such as pre-washing, grinding, and drying of plant materials to obtain a homogenous sample. It should be taken care that potential plant constituents are not degraded during 
Table 1 Important biologically active natural products encompassing 3-substituted phthalide framework

S. no.

1 (ref. 30)

2 (ref. 31)

3 (ref. 32)

4 (ref. 17)

5 (ref. 33)<smiles>C[C@H]1C[C@]2(C[C@@H](O)C(=O)O2)C[C@]2(Oc3cc4c(c(O)c3C[C@@H]2C)C(=O)O[C@@H]4[C@@H](C)O)O1</smiles>

Virgatolide A 10<smiles>C[C@H](O)[C@H]1OC(=O)c2c1cc1c(c2O)C[C@@H](C)[C@]2(C[C@@H](O)C[C@@H](C)O2)O1</smiles>

(i) Virgatolide $\mathrm{B}(\mathrm{C} 3=\alpha) \mathbf{1 1}$

(ii) Virgatolide $\mathrm{C}(\mathrm{C} 3=\beta) 12$<smiles>CC=CC1OC(=O)c2cc(O)c(O)c(O)c21</smiles>

Cytosporone E 13<smiles>C/C=C/C1=CC(=O)C([C@H]2OC(=O)c3cc(OC)cc(OC)c32)O1</smiles>

Vermistatin 14

6 (ref. 34)
Cultivated opium poppy plants

Aigialus parvus BCC

5311

Pestalotiopsis virgatula

Pestalotiopsis virgatula

Cytosora sp. CR200

Penicillium

vermiculatum DANG
Biological activities

Anti-tussive, anti-cancer, and potential antineoplastic activities
Cytotoxic against HeLa (cervical epithelium) cells
Cytotoxic against HeLa (cervical epithelium) cells 
Table 1 (Contd.)

S. no. Natural products

Isolation sources

Biological activities

7 (ref. 35)<smiles>COc1ccc2c(c1OC)C(=O)OC2</smiles><smiles>CC1CCCN(C)[C@@H]1c1cc2c(OCO)cc1CCN2C</smiles>

(-)-Hydrastine 15<smiles>COc1cccc2c1C(c1ccc3c(c1O)C(=O)[C@H](O)[C@H](C)[C@H]3OC(C)=O)OC2=O</smiles>

Rubiginone 16

(Stereochemistry at C-3 position unknown)<smiles>CCCC(=O)CC[C@H]1OC(=O)c2c1cc(OC)c(OC)c2O</smiles>

Colletotrialide 17

10 (ref. 38)

11 (ref. 39)<smiles>Cc1cc2c(c3c1C(CO[N+](=O)[O-])OC3=O)CC(C)(C)C2</smiles>

Alcyopterosin E 18<smiles>[R7]Oc1c(OC)c([R1])cc2c1C(=O)O[C@H]2CC</smiles>

(i) $\mathrm{R}_{1}=\mathrm{R}_{2}=\mathrm{H} 19$

(ii) $\mathrm{R}_{1}=\mathrm{OMe}, \mathrm{R}_{2}=\mathrm{H} \mathbf{2 0}$

(iii) $\mathrm{R}_{1}=\mathrm{OMe}, \mathrm{R}_{2}=\mathrm{Me} 20$<smiles>CC1(C)CC=C(C2OC(=O)c3ccccc32)C(=O)O1</smiles>

Catalpalactone $\mathbf{2 2}$

12 (ref. 40)
Anti-paclitaxel - resistant anticancer (ovarian) activity

Streptomyces $\mathrm{sp}$
Anti-bacterial activity, prevents the growth of specific Grampositive bacteria and cytotoxic against diverse tumor cells
Anti-oxidant and chemo preventive properties
Alcyonium paessleri
In vitro inhibitory activity on neutrophil pro-inflammatory response
Catalpa ouata G.
Cytotoxicity toward human larynx carcinoma 
Table 1 (Contd.)

S. no.

Natural products<smiles>O=C(O)c1cc(O)c(C2OC(=O)c3c(O)cc(O)cc32)c(O)c1</smiles>

Cryphonectric acid $\mathbf{2 3}$

14 (ref. 42)<smiles>[R]c1cc(O)c2c(c1)C(CC(=O)O)OC2=O</smiles>

$\mathrm{R}=\mathrm{H}$, Isoochracinic acid $\mathbf{2 4}$

$\mathrm{R}=\mathrm{OH}$, Herbaric acid 25

15 (ref. 43)<smiles>COc1ccc2c(c1OC)C(=O)O[C@]21C=Cc2cc3c(cc2C1=O)OCO3</smiles>

(-)-Arnottin II 26

16 (ref. 44)<smiles>COc1cc(O)c2c(c1)[C@@]1(CC(=O)O[C@]1(C)CC(=O)O)OC2=O</smiles>

Altenuic acid 27<smiles>O=C1OCC=C1[C@H]1CCc2ccc3c(c2C1)[C@H](c1ccco1)OC3=O</smiles>

Tilifodiolide $\mathbf{2 8}$

18 (ref. 46)<smiles>CC(=O)O[C@]1(c2ccccc2)OC(=O)c2c1ccc1c2N(C)c2cccc(C(N)=O)c2N1</smiles>

Dermacozine D 29

19 (ref. 47)

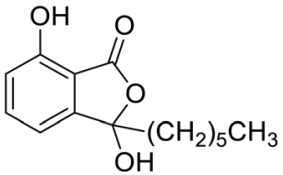

Corollosporine $\mathbf{3 0}$
Isolation sources

Biological activities
Anti-fungal activity, (inhibits the formation of tomato seedings)
Alternaria kikuchiana

(isoochracinic acid), Cladosporium herbarum (herbaric acid)

Xanthoxylum arnottianum

Alternaria tenuis

Salvia tiliaefolia and Salvia puberula

Dermacoccus abyssi

Corollospora maritima
Cytotoxic against different tumor cells lines
Anti-bacterial activity against Staphylococcus
Anti-bacterial and anti-biotic
Not known 
Table 1 (Contd.)

S. no. Natural products

20 (ref. 48)

21 (ref. 49)<smiles>CCCCC1OC(=O)c2ccccc21</smiles>

n-Butylphthalide 2<smiles>Cc1cc2c(c3c1C(CO[N+](=O)[O-])OC3=O)CC(C)(C)C2</smiles>

Alcyopterosin E 31<smiles>COc1cc(O)cc2c1C(=O)O[C@H]2C(C)C</smiles>

(+)- Spirolaxine 6<smiles>CCCCC1OC(=O)c2c(O)cccc21</smiles>

Paecilocin A 32

24 (ref. 52)<smiles>Cc1cc(O)c2c(c1)C(c1c(O)cccc1O)OC2=O</smiles>

Isopestacin $\mathbf{3 3}$

25 (ref. 53)

26 (ref. 54)

\section{Matteucen C 34}<smiles>Cc1c(O)cc2c(c1O)C(=O)OC2[C@H](C)O</smiles>

Isolation sources

Apium graveolens, Angelica sinensis

Subantarctic soft coral Alcyonium paessleri

Fungus Sporotrichum laxum

Fungus Paecilomyces variotii

Pestalotiopsis microspora

Chineses medicinal herb Matteuccia orientalis for the treatment of hemostatics and reliving ostalgia

Solid culture of an isolate of Pestalotiopsis foedans
Anti-convulsant, anti-stroke and anti-proliferative
Toxic towards Hep-2 (human larynx carcinoma) cell line
Anti-tumor and active against Helicobacter pylori, also, lower the cholesterol level in the body
Anti-bacterial activity against pathogenic bacteria including Staphylococcus aureus 3089 and Vibrio parahaemolyticus 7001

Anti-fungal activity

(3S)- Pestaphthalides A 35a

(3R)- Pestaphthalides A 35b 
Table 1 (Contd.)

S. no. 27 (ref. 55)

Paecilomycin $\mathrm{C}\left(\mathrm{R}^{1}=\mathrm{H}, \mathrm{R}^{2}=\mathrm{OH}\right) 36$

Paecilomycin D $\left(\mathrm{R}^{1}=\mathrm{OH}, \mathrm{R}^{2}=\mathrm{H}\right) 37$<smiles>C[C@H](CCC1OC(=O)c2ccccc21)OC(O)C(C)(C)C(O)(O)CO</smiles>

Celephthalide A 38

29 (ref. 57)<smiles>CC[C@H]1OC(=O)c2c1ccc1ccoc21</smiles>

Concentricolide 39

30 (ref. 58)<smiles>Cc1cccc2c3c(ccc12)C1(C[C@H](C)CO1)OC3=O</smiles>

Danshenspiroketallactone 40<smiles>O=C1OC(c2cccs2)c2cccc(O)c21</smiles>

Chrycolide 41<smiles>O=C1O[C@H](Cc2ccccc2)c2cccc(O)c21</smiles>

Typhaphthalide 42
Celery seed

Ascomycete Daldinia concentrica

Traditional Chinese medicine consisting of Salvia miltiorrhiza

Leaves and stem of a popular vegetable Chrysanthemum coronarium

Rhizomes of Typha capensis
A diuretic for bladder and kidney complaints and adjuvant in arthritic conditions

Anti-HIV-1

Immunosuppressants and antistroke

Anti-feeding activity

Anti-bacterial activity against diarrhea and dysentery 
Table 1 (Contd.)

S. no.

Natural products<smiles>COc1cc(OC)c2c(c1)[C@H](Cc1cc(OC)c3c(c1)OCO3)OC2=O</smiles>

3a- [4'- Methoxy-4',5'methyllenedioxybenzyl]-5,7-

dimethoxyphthalide $\mathbf{4 3}$

34 (ref. 62)<smiles>CCCC(=O)CCC1OC(=O)c2c1cc(OC)c(OC)c2O</smiles>

Colletotrialide 44

35 (ref. 63)<smiles>COc1cc(O)c2c(c1C)[C@](C)(C(C)=O)OC2=O</smiles>

(R)-3-acetyl-7-hydroxy-5-methoxy3,4-dimethylisobenzofuran-1(3H)one 45<smiles>CC[C@H](C)[C@H](O)[C@H]1OC(=O)c2c(O)c(C)cc(C)c21</smiles>

Chrysoarticulin C 46

37 (ref. 65)<smiles>CCC/C=C1\OC(=O)C2=C1CCC=C2</smiles>

Z-Ligustilide 47<smiles>CN1CCc2cc3c(cc2[C@@H]1[C@H]1OC(=O)c2c1ccc1c2OCO1)OCO3</smiles>

38 (ref. 66)
Isolation sources

Frullania sp.

Euryops hebecarpus

Endophytic fungus

Leptosphaeria sp.

Ligusticum porteri

Fumaria capreokzta $\mathrm{L}$ and Fumaria bella
Biological activities

Cytotoxic against human promyelocytic leukemia
Not known

Anti-oxidant activity

(+)- Bicuculine 48

Anti-proliferative activity (sedative and relaxant)
Potent GABa receptor antagonist and used to block $\mathrm{Ca}^{2+}$ activated potassium channels extraction. The selection of solvent also plays a crucial role in the extraction of phthalides, and it largely depends upon the nature of the phthalides. Most phthalides are non-polar, so for the extraction of such molecules, hexane or petroleum ether can be used as an initial extraction solvent. To extract polar phthalides, we use polar solvents, such as ethanol, chloroform, 
methanol, and ethyl-acetate. ${ }^{\mathbf{2 1 , 2 4}}$ The extraction process for phthalides has remained mostly unchanged over the years; however, some upgraded extraction procedures have been reported. ${ }^{25,26}$

Phthalides are usually isolated via column chromatography, thin layer chromatography (TLC), and HPLC, with column chromatography being the most common. Silica, alumina, and LH-20 are frequently used adsorbents for column chromatography. ${ }^{27,28}$ Other techniques that have been used for some specific phthalides include preparative TLC (PTLC), centrifugal circular TLC (CCTLC), medium-pressure liquid chromatography (MPLC), high-speed countercurrent chromatography (HSCCC), droplet-countercurrent chromatography (DCCC), and high-vacuum low-temperature distillation. ${ }^{29}$

Initially, the characterization of naturally occurring phthalides was carried out through melting points, boiling points, saponification, UV spectroscopy, and hydrolysis techniques. After the development of NMR, IR, GC-MS, and X-ray crystallography, characterizing phthalides has become much easier.

\section{Isolated natural products encompassing 3-substituted phthalide framework}

Table 1 summarises examples of isolated natural products encompassing 3-substituted phthalide framework

\section{Synthetic routes for 3-substituted $1(3 H)$-isobenzofuranones}

We have classified synthetic routes to access 3-substituted $( \pm)$-1 $(3 H)$-isobenzofuranones in two major titles. First, we have emphasized recent approaches to generate racemic 3substituted $( \pm)-1(3 H)$-isobenzofuranones, and later we have described recent approaches to generate optically pure 3substituted 1(3H)-isobenzofuranones.

\subsection{Recent methodologies for the synthesis of 3-substituted $( \pm)$-1(3H)-isobenzofuranones}

3.1.1 Metal catalyzed synthesis of 3-substituted $( \pm)-1(3 H)-$ isobenzofuranones. Fan and co-workers ${ }^{67}$ have reported 3substituted phthalides $\mathbf{5 1}$ via a ruthenium-catalyzed intermolecular cascade reaction of aromatic acids 49 with aromatic aldehydes 50. The synthesis involves the direct insertion of the $\mathrm{C}-\mathrm{H}$ bond of the aromatic acids into a polar $\mathrm{C}=\mathrm{O}$ bond of aromatic aldehydes, which is followed by the consecutive intramolecular nucleophilic substitution. The polarity (electrophilicity) of the $\mathrm{C}=\mathrm{O}$ bond in aromatic aldehydes was increased by having electron-withdrawing groups $\left(\mathrm{NO}_{2}, \mathrm{CF}_{3}, \mathrm{~F}, \mathrm{Cl}, \mathrm{Br}\right)$ on the aromatic ring (Scheme 1).

Nguyen and co-workers ${ }^{68}$ demonstrated a direct route to obtain phthalides 53 via carboxylation of benzoxasiloles 52 with carbon dioxide, using CuI as a catalyst. Several advantages of this methodology are the use of copper salt as a catalyst, economical starting materials and convenient reaction setup (Scheme 2). The main challenge of this methodology was the unexplored reactivity of organosilanes with $\mathrm{CO}_{2}$.

Arcadi and co-workers ${ }^{69}$ have described a palladiumcatalyzed hydroarylation and hydrovinylation reaction of $\gamma$ propargylic alcohols 54 with aryl iodides 55 to afford crude $\gamma, \gamma$ disubstituted allylic alcohols 56. Allylic alcohols 56 were treated with $\mathrm{NaOH}$ followed by acidification afforded 3,3-disubstituted phthalides 59 in good to moderate yields (Scheme 3).

Matsuda and co-workers ${ }^{70}$ described an oxidative cyclization of phthalaldehydes $\mathbf{6 0}$ and alcohols catalyzed by rhodium(III) catalyst and copper acetate to afford 3-alkoxyphthalides 61 in good to moderate yields (Scheme 4). The reaction is believed to be proceeding via $\mathrm{Rh}-\mathrm{Cu}$ relay catalytic system.

The work was further extended to explore the utility of 1,3dicarbonyl compounds $\mathbf{6 3}$ as nucleophiles for the reaction with phthalaldehydes 62 under similar conditions. This led to the synthesis of 3-alkylphthalides 64 in excellent yields (Scheme 5).

Gandeepan and co-workers ${ }^{71}$ demonstrated rhodium(III)catalyzed regio- and stereoselective synthesis of disubstituted $E$ phthalides 67 from aryl acids 65 and allenes 66. The reaction proceeded via ortho $\mathrm{C}-\mathrm{H}$ bond activation followed by an annulation pathway. The scope of the methodology was further investigated on a variety of aryl acids 65 and allenes 66 (Scheme $6)$.

3.1.2 Hydroiodination-triggered synthesis of 3-substituted $( \pm)$-1(3H)-isobenzofuranones. Hydroiodination-triggered cascade reaction is demonstrated by Kawaguchi and coworkers ${ }^{72}$ by using $\mathrm{I}_{2}, \mathrm{PPh}_{3}$, and $\mathrm{H}_{2} \mathrm{O}$ in $\mathrm{CDCl}_{3}$ to furnish 3substituted phthalides 69 in excellent yields. The reaction proceeds via a four-step sequence, i.e., desilylation, hydroiodination, cyclization, and reduction, in one pot (Scheme 7). The present method eliminates the need for a metal catalyst to form phthalides.

The substrate scope of 2-ethynylbenzoates 70 was also studied by using cyano, chloro, phenyl, and ester groups on the side chain. They were tolerated during the four-step sequence to provide 3-substituted phthalides $\mathbf{7 1}$ (Scheme 8).

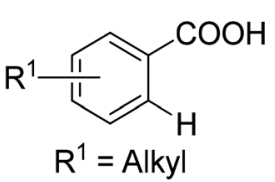

49<smiles>O=CBr</smiles>

50

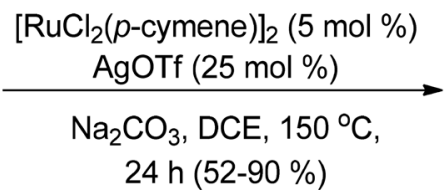

$24 \mathrm{~h}(52-90 \%)$<smiles>[R][I-]c1ccc2c(c1)C(=O)OC2[Bi]</smiles>

51

Scheme 1 Ruthenium catalyzed the synthesis of 3-substituted phthalides. 
<smiles>[R1]c1ccc2c(c1)[Si]([P-]C)(C(C)C)OC2[R]</smiles>

52

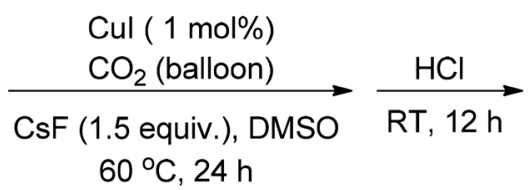

$60^{\circ} \mathrm{C}, 24 \mathrm{~h}$<smiles>[R]C1OC(=O)c2cc[R]([H])cc21</smiles>

53

$$
\begin{aligned}
& \mathrm{R}^{1}=6-\mathrm{Me}, \mathrm{R}^{2}=\mathrm{H}(77 \%) \\
& \mathrm{R}^{1}=6-\mathrm{NMe} \mathrm{e}_{2}, \mathrm{R}^{2}=\mathrm{H}(72 \%) \\
& \mathrm{R}^{1}=6-\mathrm{F}, \mathrm{R}^{2}=\mathrm{H}(77 \%) \\
& \mathrm{R}^{1}=6-\mathrm{Cl}, \mathrm{R}^{2}=\mathrm{H}(80 \%) \\
& \mathrm{R}^{1}=5-\mathrm{OMe}, \mathrm{R}^{2}=\mathrm{H}(68 \%) \\
& \mathrm{R}^{1}=4-\mathrm{OMe}, \mathrm{R}^{2}=\mathrm{H}(76 \%) \\
& \mathrm{R}^{1}=4-\mathrm{Me}, \mathrm{R}^{2}=\mathrm{H}(77 \%) \\
& \mathrm{R}^{1}=6-\mathrm{Me}, \mathrm{R}^{2}=\mathrm{Me}(82 \%) \\
& \mathrm{R}^{1}=5-\mathrm{OMe}, \mathrm{R}^{2}=\mathrm{Me}(83 \%) \\
& \mathrm{R}^{1}=4-\mathrm{OMe}, \mathrm{R}^{2}=\mathrm{Me}(79 \%) \\
& \mathrm{R}^{1}=4-\mathrm{Me}, \mathrm{R}^{2}=\mathrm{OH}(68 \%)
\end{aligned}
$$

Scheme 2 Synthesis of benzoxasiloles via copper-catalyzed direct carboxylation.

3.1.3 Synthesis of 3-substituted $( \pm)$-1(3H)-isobenzofuranones using $\beta$-keto acids as a nucleophile center. Jia and co-workers ${ }^{73}$ developed a one-pot cascade aldol/cyclization reaction of $\mathbf{7 2}$ wherein $\beta$-keto acids $\mathbf{7 3}$ were directly employed as a nucleophilic center, and glycerol was used as a solvent. Here, $\beta$-keto acids functioned as ketone enolate equivalents. An extensive substrate scope for $\beta$-keto acids was explored, affording a wide variety of 3 -substituted phthalides in good to excellent yields (Scheme 9).

3.1.4 Synthesis of 3-substituted $( \pm)-1(3 H)$-isobenzofuranones using Schiff base. Perillo and co-workers ${ }^{74}$ developed cascade reaction of glycine Schiff base 77 with 2carbomethoxy benzaldehyde 76, which involved aldol condensation followed by cyclization under the acidic conditions to provide $\alpha$-amino ester 3 -substituted phthalides $\mathbf{8 0}$ in good yield (Scheme 10). The methodology was further extended to develop an enantioselective version of the reaction to obtain chiral 3substituted phthalides in high ee's. ${ }^{73}$

A variety of bifunctional phase-transfer catalysts (PTC) were examined to obtain 3-substituted phthalides in excellent enantioselectivity. Bifunctional PTC 75 (Fig. 5) gave the desired product in moderate ee's $(51-71 \%) .^{73}$
3.1.5 Oxa-Michael addition reaction to generate 3substituted $( \pm)-\mathbf{1}(3 \mathrm{H})$-isobenzofuranones. Youn and coworkers ${ }^{75}$ have developed NHC-catalyzed domino oxidation of 2alkenylbenzaldehydes $\mathbf{8 1}$, followed by oxa-Michael addition reaction to afford 3-substituted phthalides $\mathbf{8 3}$. The protocol developed has a broad substrate scope and wide functional group tolerance. The success of the domino process could be achieved in two ways; by exploiting atmospheric oxygen as an oxygen atom source and by adding an electron-deficient olefin bearing hetero atom with lone pair of electrons. Also, molecular oxygen in air could play an essential role in transformation, as similar NHC-catalyzed reactions of the same substrates under inert atmosphere produce follow different reaction pathways (Scheme 11).

3.1.6 Friedel-Crafts alkylation reaction to generate 3substituted $( \pm)-\mathbf{1}(3 H)$-isobenzofuranones. Tang and coworkers $^{76}$ have developed an efficient methodology to synthesize 3-indolyl-substituted phthalides $\mathbf{8 6}$ via Friedel-Crafts alkylation of indoles 85 with 3-hydroxy phthalide 84 using $\mathrm{TsOH}$ as the catalyst. The usefulness of the process was studied with variously substituted indoles which reacted efficiently at room temperature to afford phthalides in excellent yields (Scheme 12).

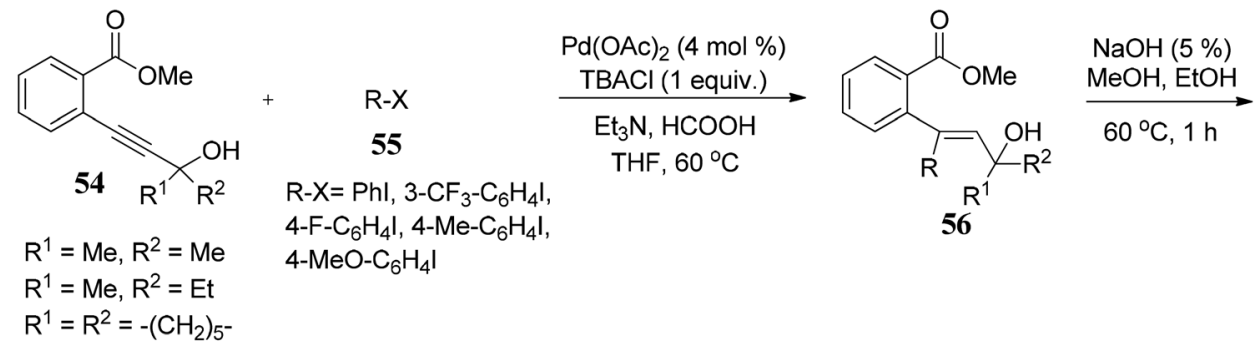<smiles>[R]C1=CC([R])([R])OC(=O)c2ccccc21</smiles>

57

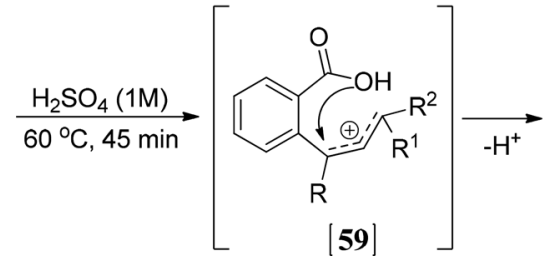

[59]

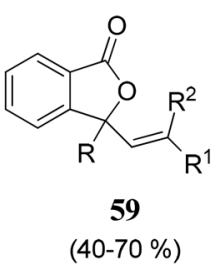

Scheme 3 Synthesis of 3-vinyl phthalides. 


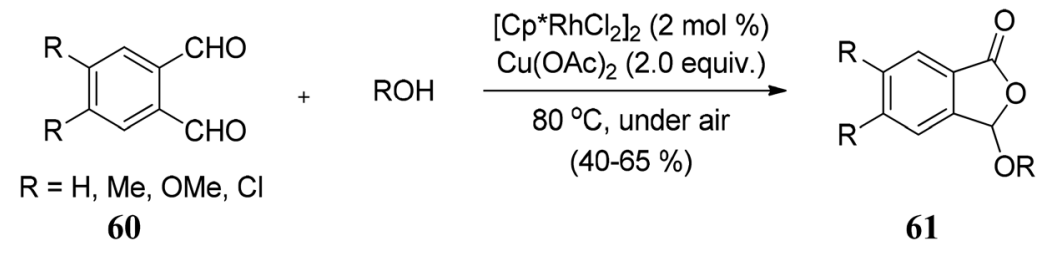

Scheme 4 Synthesis of 3-alkoxy phthalides.

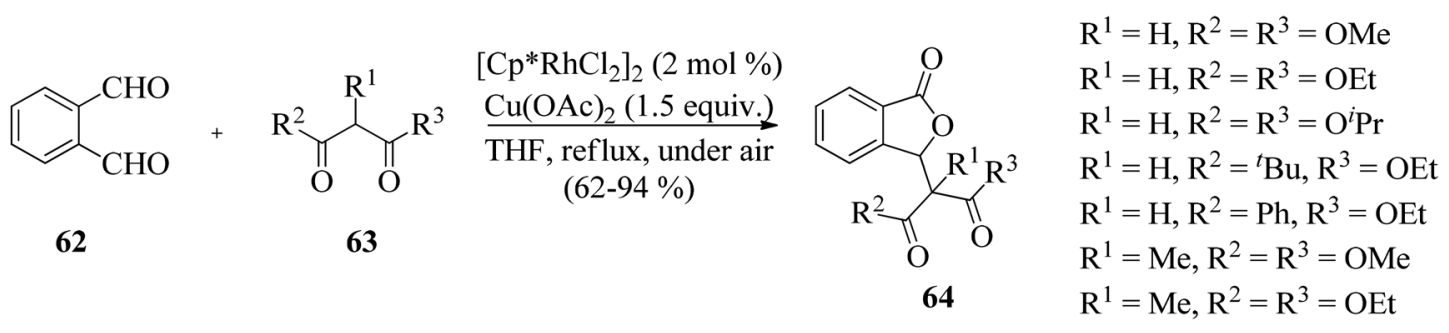

Scheme 5 Synthesis of 3-alkyl phthalides.<smiles>[R]c1ccc(C(=O)O)cc1</smiles>

65

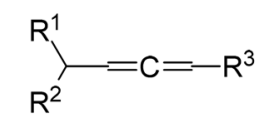

66

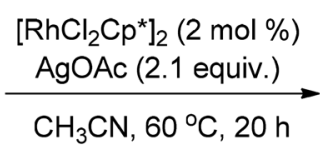

$(57-92 \%)$

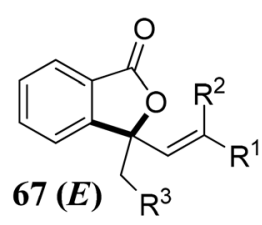

$67(E) \quad \mathrm{R}^{3}$

$$
\begin{array}{ll}
\mathrm{R}=\mathrm{H}, \text { 4-Me, 4-OMe, 4-F, } & \mathrm{R}^{1}=\text { 3-Me-Ph, } \mathrm{R}^{2}=\mathrm{R}^{3}=\mathrm{H} \\
\text { 4-Cl, 4-Br, 4-I, 4-NO } \mathrm{NO}_{2}, 4-\mathrm{CN}, & \mathrm{R}^{1}=\text { 1-napthyl, } \mathrm{R}^{2}=\mathrm{R}^{3}=\mathrm{H} \\
\text { 2-Me, 2-CI, 3-Me, 3-F, 3-I, } & \mathrm{R}^{1}=\mathrm{CH}_{2} \mathrm{Ph}, \mathrm{R}^{2}=\mathrm{R}^{3}=\mathrm{H} \\
\text { 3-OMe, 3-Cl, 3-Br } & \mathrm{R}^{1}=\mathrm{CH}_{2} \mathrm{CH}_{2} \mathrm{Ph}, \mathrm{R}^{2}=\mathrm{R}^{3}=\mathrm{H} \\
& \mathrm{R}^{1}=\mathrm{C}\left(\mathrm{CH}_{3}\right)_{2} \mathrm{Ph}, \mathrm{R}^{2}=\mathrm{R}^{3}=\mathrm{H} \\
& \mathrm{R}^{1}=\mathrm{Ph}^{2} \mathrm{R}^{2}=\mathrm{Me}, \mathrm{R}^{3}=\mathrm{H} \\
& \mathrm{R}^{1}=\mathrm{CO}_{2} \mathrm{Et}, \mathrm{R}^{2}=\mathrm{R}^{3}=\mathrm{H}
\end{array}
$$

$$
\begin{aligned}
& R^{1}=\mathrm{CH}_{2} \mathrm{OH}, \mathrm{R}^{2}=\mathrm{R}^{3}=\mathrm{H} \\
& \mathrm{R}^{1}=\mathrm{SiMe}_{3}, \mathrm{R}^{2}=\mathrm{R}^{3}=\mathrm{H} \\
& \mathrm{R}^{1}=\mathrm{Ph}, \mathrm{R}^{2}=\mathrm{H}, \mathrm{R}^{3}=\mathrm{CH}_{2} \mathrm{Ph} \\
& \mathrm{R}^{1}=\mathrm{Ph}, \mathrm{R}^{2}=\mathrm{H}, \mathrm{R}^{3}=\mathrm{Me} \\
& \mathrm{R}^{1}=\mathrm{CO}_{2} \mathrm{Et}, \mathrm{R}^{2}=\mathrm{H}, \mathrm{R}^{3}=\mathrm{Me}
\end{aligned}
$$

Scheme 6 Scope of arenecarboxylic acids and allenes (synthesis of disubstituted phthalides).<smiles>[R]c1ccc(C(=O)OC)c(C#CC[AsH2])c1</smiles>
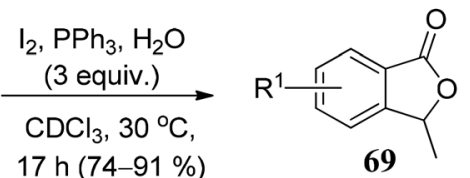

$\mathrm{R}^{1}=\mathrm{Me}, \mathrm{OMe}, \mathrm{F}, \mathrm{Cl}, \mathrm{CF}_{3}$

Scheme 7 Hydroiodination-triggered synthesis of 3methylphthalides.

3.1.7 NBS mediated free-radical bromination to generate 3substituted $( \pm)-\mathbf{1}(\mathbf{3 H})$ isobenzofuranones. Li and co-workers ${ }^{77}$ have devised a four-step strategy for the synthesis of 3substituted phthalide. The condensation reaction of 3-ethoxyphthalide 89 with diethylmalonate carbanion followed by decarboxylation and hydrolysis gave 3-substituted phthalides 92 in $44 \%$ overall yield over four steps (Scheme 13). NBS mediated free-radical bromination of phthalide $\mathbf{8 7}$ gives $\mathbf{8 8}$. The crude $\mathbf{8 8}$ was treated with hot ethanol, then cooled to give $\mathbf{8 9}$ as white solid.

3.1.8 Photochemical catalyzed synthesis of 3-substituted $( \pm)$-1(3H)-isobenzofuranones. Tatsugi and co-workers ${ }^{78}$ demonstrated that the degassed alcoholic solution of indane1,2,3-trione 93 could be photochemically irradiated to afford 3-alkoxycarbonylphthalides $\mathbf{9 4}$ as the major product. During the process, 3-alkoxyphthalide 95 was also obtained in minor quantities (Scheme 14).

The initial step of the photochemical process could be the cleavage of a $\mathrm{C}-\mathrm{O}$ bond to form semidione radical 93a, which under rearrangement forms $\mathbf{9 3 \mathbf { b }}$. Thus, 93b can follow two pathways: (i) it can form the compound 93c, which on reaction with $\mathrm{ROH}$ forms 93d followed by protonation to give 3-alkoxycarbonylphthalides $\mathbf{9 4}$ or (ii) $\mathbf{9 3 f}$ rearranges to $\mathbf{9 3} \mathrm{g}$ followed by decarbonylation gave phthalides carbene which on quenching with ROH gave 3-alkoxyphthalide 95 (Scheme 15). 
<smiles>[R]C#Cc1ccc([R])cc1C(=O)OC</smiles>

$\mathrm{R}^{1}=\mathrm{Me}, \mathrm{OMe}$
$\mathrm{I}_{2}, \mathrm{PPh}_{3}, \mathrm{H}_{2} \mathrm{O}$

$\underset{\mathrm{CDCl}_{3}, 30^{\circ} \mathrm{C} \text {, }}{\stackrel{(3 \text { equiv. }}{\longrightarrow}}$

$17 \mathrm{~h}(64-81 \%)$<smiles>[R]CC1OC(=O)C2=CC=[R][X]C=C21</smiles>

$\mathrm{R}^{2}=-\mathrm{H},-\left(\mathrm{CH}_{2}\right)_{3} \mathrm{Cl},-\left(\mathrm{CH}_{2}\right)_{3} \mathrm{l},-\left(\mathrm{CH}_{2}\right)_{3} \mathrm{CN}$

$-\left(\mathrm{CH}_{2}\right)_{3} \mathrm{Ph},-\left(\mathrm{CH}_{2}\right)_{3} \mathrm{COOMe}$

Scheme 8 Synthesis of 3-substituted phthalides triggered via hydroiodination.<smiles>[R]c1ccc(C=O)c(C(=O)O)c1</smiles>

72<smiles>[R]C(=O)CC(=O)O</smiles>

73

p-anisidine $(20 \mathrm{~mol} \%)$

glycerol, $65^{\circ} \mathrm{C}, 30 \mathrm{~min}$

(65-85\%)<smiles>[R][R]1ccc2c(c1)C(CC([R])=O)OC2=O</smiles>

74

Scheme 9 Synthesis of 3 -substituted phthalides using $\beta$-keto acids as a nucleophile center.<smiles>COC(=O)c1ccccc1C=O</smiles><smiles>CCCCOC(=O)CN=C(c1ccccc1)c1ccccc1</smiles><smiles>[Mg][Mg][Mg][Mg]</smiles>
$\mathrm{CH}_{3} \mathrm{CN} / \mathrm{DCM}$ 77

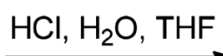<smiles>CC(C)(C)OC(=O)C(N=C(c1ccccc1)c1ccccc1)C1OC(=O)c2ccccc21</smiles>

$\mathrm{dr}=67: 33(80 \%)$

79<smiles>CCCCCCCCCCCC(C)=NC(c1ccccc1)C(O)c1ccccc1C(=O)OC</smiles><smiles>CC(C)(C)OC(=O)C(N)C1OC(=O)c2ccccc21</smiles>

$(80 \%)$

80

Scheme 10 Synthesis of $\alpha$-amino ester 3 -substituted phthalide.

\subsection{Recent methodologies to synthesize enantiomerically pure 3-substituted $\mathbf{1}(3 \mathrm{H})$-isobenzofuranes}

In this section, we have described recent approaches to synthesize enantiomerically pure 3-substituted $1(3 H)$ isobenzofuranes.

3.2.1 Synthesis of 3-substituted $\mathbf{1}(3 \mathrm{H})$-isobenzofuranones using diverse organozinc reagents. Huang and co-workers ${ }^{79}$ demonstrated a new protocol for the synthesis of chiral 3substituted phthalides 99 by carrying out catalytic asymmetric 1,2-addition of methyl 2-formylbenzoates $\mathbf{9 8}$, followed by lactonization, using diverse organozinc reagents (Scheme 16).
They developed a chiral phosphoramide ligand-Zn(II) complex, which was synthesized from $(1 R, 2 R)$-diphenylethyelendiamine 100 as catalyst. The efficiency of the process is highlighted by the fact that the enantiopure phthalide 99 was obtained in excellent yields $(\sim 95 \%)$ and good enantioselectivities $(\sim 89 \%)$.

Carlos and co-workers ${ }^{\mathbf{8 0}}$ carried out the asymmetric catalytic synthesis of 3-aryl phthalides 102 via sequential asymmetric arylation-lactonization pathway. In the presence of a chiral amino naphthol ligand, the reactive arylating agents, generated by boron-zinc exchange, were reacted with 2-formylbenzoates 101, which was followed by lactonization to yield the corresponding chiral phthalides $\mathbf{1 0 2}$ in excellent yields and 


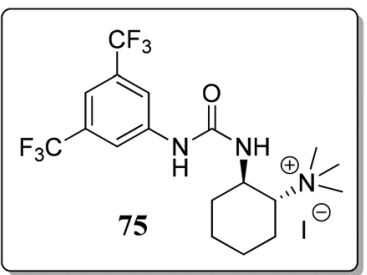

Fig. 5 Bifunctional phase-transfer catalyst.

enantioselectivities ( $\sim 87-90 \%$ ee) (Scheme 17$)$. The place of the substituent at the aryl ring was found to have a slight effect on the efficiency of the arylation reactions. The asymmetric addition of an aryl zinc reagent to the 2-formylbenzoate is the enantio determining step.

3.2.2 Synthesis of chiral 3-substituted phthalides via palladium-catalyzed Heck-Matsuda arylation of arenediazonium salt. Kattela and co-workers ${ }^{81}$ have described an enantioselective synthesis of chiral 3-substituted phthalides via palladium-catalyzed Heck-Matsuda arylation of arenediazonium salt 104 with 2,3-dihydrofurans 105, followed by $\mathrm{NaBH}_{4}$ mediated reduction and lactonization pathway to give chiral phthalides 107 in overall yields and excellent enantioselectivities (up to $98 \%$ ee). The strategy was further extended for the synthesis of medicinally important chiral lactones, amines, and olefins (Scheme 18).
3.2.3 Novel derived metal complex ligand as a catalyst for the synthesis of chiral 3-substituted phthalides. Ge and coworkers $^{82}$ have developed the first asymmetric hydrogenation of 3-alkyl/arylidenephthalides 108 to furnish an extensive range of 3-substituted chiral phthalides 109 in admirable enantiomeric excesses ( $\sim 98 \%$ ee). The hydrogenation process was catalyzed by a novel derived $\operatorname{Ir}^{\mathrm{I}}$ complex of a spiro-[4,4]-1,6-nonadienebased phosphine-oxazoline ligand (SpinPHOX) 110 as a catalyst. The effectiveness of the protocol further extended for the asymmetric synthesis of enantioselective drugs as well as the bioactive natural products (Scheme 19).

Zhang and co-workers ${ }^{83}$ demonstrated a novel route for the reductive cyclization of 2-acylarylcarboxylate 111 via asymmetric transfer hydrogenation. The reaction was promoted by a new $\mathrm{Ru}(\mathrm{II})$-diamine complex 113, which catalyzes asymmetric transfer hydrogenation and in situ lactonization to provide enantiomerically pure 3-substituted phthalides 112 (Scheme 20).

The observed excellent enantioselectivity can be explained by a preferable transition state of the Ru-TsDBuPEN complex and ethyl 2-acylarylcarboxylate substrates, which determines the chirality. Hydrogen bonding with the neighboring ester function group of the 2-acylarylcarboxylate substrate might also be accountable for the observed selectivity (Fig. 6).

Kumbhar and co-workers ${ }^{84}$ synthesized bipyridyl ligands. These chiral ligands were applied in the synthesis of chiral phthalides. The reaction sequence involved chromiumcatalyzed enantioselective Nozaki-Hiyama-Kishi allylation of<smiles>[R]C=Cc1cc([R])c([R])c([R])c1C=O</smiles>

81

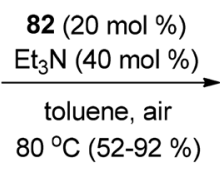

$80^{\circ} \mathrm{C}(52-92 \%)$

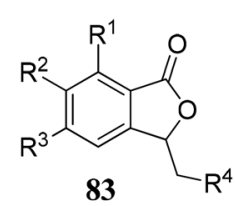

83

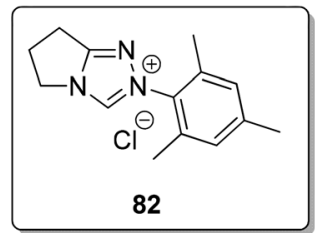

$$
\begin{array}{l:l}
\mathrm{R}^{1}=\mathrm{R}^{2}=\mathrm{R}^{3}=\mathrm{H}, \mathrm{R}^{4}=\mathrm{CO}_{2} \mathrm{Et} & \mathrm{R}^{1}=\mathrm{R}^{2}=\mathrm{R}^{3}=\mathrm{H}, \mathrm{R}^{4}=\mathrm{COPh} \\
\mathrm{R}^{1}=\mathrm{R}^{2}=\mathrm{R}^{3}=\mathrm{H}, \mathrm{R}^{4}=\mathrm{CO}_{2} \mathrm{Me} & \mathrm{R}^{1}=\mathrm{R}^{2}=\mathrm{R}^{3}=\mathrm{H}, \mathrm{R}^{4}=\mathrm{PO}(\mathrm{OEt})_{2} \\
\mathrm{R}^{1}=\mathrm{R}^{2}=\mathrm{R}^{3}=\mathrm{H}, \mathrm{R}^{4}=\mathrm{CO}_{2}{ }^{n} \mathrm{Bu} & \mathrm{R}^{1}=\mathrm{R}^{2}=\mathrm{H}, \mathrm{R}^{3}=\mathrm{Me}, \mathrm{R}^{4}=\mathrm{CO}_{2} \mathrm{Et} \\
\mathrm{R}^{1}=\mathrm{R}^{2}=\mathrm{R}^{3}=\mathrm{H}, \mathrm{R}^{4}=\mathrm{CO}_{2}{ }^{t} \mathrm{Bu} & \mathrm{R}^{1}=\mathrm{H}, \mathrm{R}^{2}=\mathrm{OMe}, \mathrm{R}^{3}=\mathrm{H}, \mathrm{R}^{4}=\mathrm{CO}_{2} \mathrm{Et} \\
\mathrm{R}^{1}=\mathrm{R}^{2}=\mathrm{R}^{3}=\mathrm{H}, \mathrm{R}^{4}=\mathrm{CONMe} & \mathrm{R}^{1}=\mathrm{H}, \mathrm{R}^{2}=\mathrm{OMe}, \mathrm{R}^{3}=\mathrm{H}, \mathrm{R}^{4}=\mathrm{CO}_{2}{ }^{t} \mathrm{Bu} \\
\mathrm{R}^{1}=\mathrm{R}^{2}=\mathrm{R}^{3}=\mathrm{H}, \mathrm{R}^{4}=\mathrm{CN} & \mathrm{R}^{1}=\mathrm{H}, \mathrm{R}^{2}=\mathrm{OMe}, \mathrm{R}^{3}=\mathrm{OMe}, \mathrm{R}^{4}=\mathrm{CO}_{2} \mathrm{Et} \\
\mathrm{R}^{1}=\mathrm{R}^{2}=\mathrm{R}^{3}=\mathrm{H}, \mathrm{R}^{4}=\mathrm{COMe} & \mathrm{R}^{1}=\mathrm{OMe}, \mathrm{R}^{2}=\mathrm{H}, \mathrm{R}^{3}=\mathrm{H}, \mathrm{R}^{4}=\mathrm{CO}_{2} \mathrm{Me} \\
\mathrm{R}^{1}=\mathrm{R}^{2}=\mathrm{R}^{3}=\mathrm{H}, \mathrm{R}^{4}=\mathrm{COEt} & \mathrm{R}^{1}=\mathrm{H}, \mathrm{R}^{2}=\mathrm{Cl}, \mathrm{R}^{3}=\mathrm{H}, \mathrm{R}^{4}=\mathrm{CO}_{2} \mathrm{Et} \\
& \mathrm{R}^{1}=\mathrm{H}, \mathrm{R}^{2}=\mathrm{F}, \mathrm{R}^{3}=\mathrm{H}, \mathrm{R}^{4}=\mathrm{CO}_{2} \mathrm{Et}
\end{array}
$$

Scheme 11 NHC-catalyzed domino oxidation/oxa-Michael addition of 2-alkenylbenzaldehydes.<smiles>O=C1OC(O)c2ccccc21</smiles><smiles>C1CCCCC1</smiles><smiles>c1ccc2[nH]ccc2c1</smiles><smiles>CC(=O)OCC(=O)O</smiles>
$(95 \%)$

84<smiles>O=C1OC(c2c[nH]c3ccccc23)c2ccccc21</smiles>

86

Scheme 12 Synthesis of 3-indolyl-substituted phthalides. 


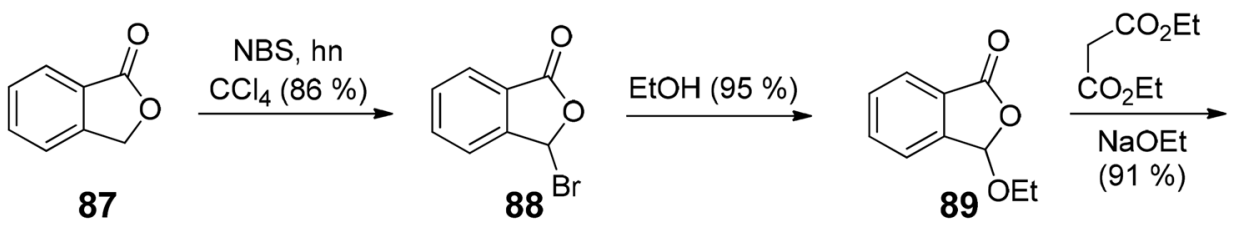

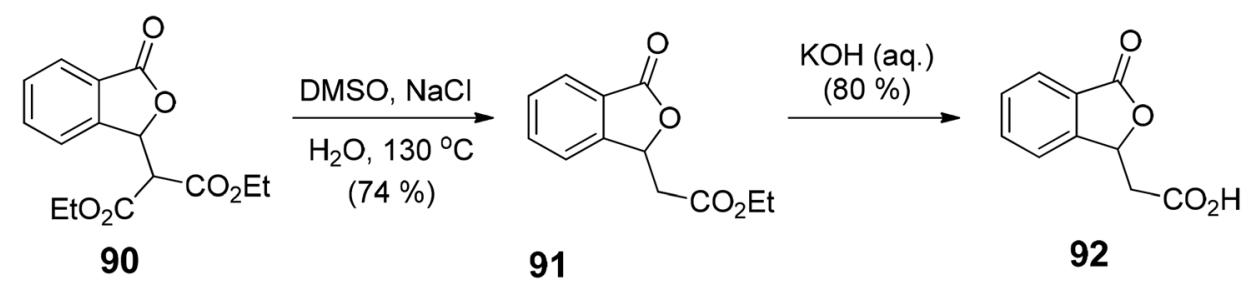

Scheme 13 Synthesis of 3-substituted phthalides.<smiles>O=c1c(=O)c2ccccc2c1=O</smiles>

93

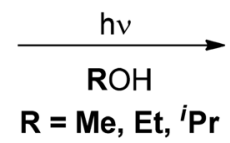

$\mathrm{R}=\mathrm{Me}, \mathrm{Et},{ }^{i} \mathrm{Pr}$ substituted benzaldehydes 114, followed by lactonization gave enantiopure phthalides 116 with an optimal ee of 99\%. Chiral $\mathrm{Cr}(\mathrm{II})$ complex developed using bipyridine alcohol and $\mathrm{CrCl}_{3}$. This utility of the protocol was further extended by accomplishing the synthesis of $(S)$-cytosporone $\mathrm{E}$ in three steps (Scheme 21).

$\mathrm{Lu}$ and co-workers ${ }^{85}$ established an extremely effective and enantioselective approach towards the synthesis of bioactive 3substituted chiral phthalides 119. The protocol involved ruthenium-catalyzed hydrogenation followed by lactonization of 2-acylarylcarboxylates $\mathbf{1 1 7}$ to furnish 3-substituted chiral phthalides. Different chiral phosphine ligands were employed to obtain good enantioselectivity, the best among them was $(S)$ SunPhos 118, which helped in the induction of enantioselectivity $>99 \%$ ee (Scheme 22 ).

3.2.4 Chiral bifunctional cinchonine as an organocatalyst for the synthesis of chiral 3-substituted phthalides. Youn and co-workers ${ }^{86}$ developed an asymmetric domino oxidation/oxaMichael addition reaction wherein an N-heterocyclic carbene (NHC) 121 and a chiral bifunctional cinchonine organocatalyst 122 work cooperativity to furnish the chiral 3 -substituted phthalides 123. The use of a bifunctional cinchonine catalyst helps in achieving excellent enantioselectivity, where it functions both as a base (quinuclidine) and hydrogen bond donor, thus activating nucleophile and electrophile, respectively. Cinchonine works both as a Brønsted base for the generation of<smiles>[R]OC(=O)C1OC(=O)c2ccccc21</smiles>

94

$\begin{array}{ll}\mathrm{R}=\mathrm{Me} & 57 \% \\ \mathrm{R}=\mathrm{Et} & 54 \% \\ \mathrm{R}={ }^{i} \mathrm{Pr} & 35 \%\end{array}$<smiles>[R]OC1OC(=O)c2ccccc21</smiles>

95

$21 \%$

$12 \%$

$5 \%$
NHC as well as a bifunctional catalyst for asymmetric induction (Scheme 23).

3.2.5 Synthesis of chiral 3-substituted phthalides via a nucleophilic addition reaction. Zhang and co-workers ${ }^{87}$ described a two-step asymmetric route for 3-substituted phthalides 130. The chiral amide $\mathbf{1 2 6}$ was subjected to the treatment with isopropyl magnesium chloride followed by reaction with various aldehydes 128 (Scheme 24). Intramolecular cyclization of the substrate allowed the synthesis of 3substituted phthalides 130 ( $\sim 88 \%$ ee).

Davis and co-workers ${ }^{88}$ developed an enantioselective approach towards the synthesis of 3-substituted phthalides by the addition of phthalide anions 133 to chiral-sulfinimines ( $N$ sulfinyl imines) 132. The present approach was extended for the synthesis of chiral 3-substituted isoquinolones and 3substituted 4-hydroxy isoquinolines, respectively (Scheme 25).

3.2.6 Tandem aldol-lactonization reactions for the synthesis of chiral 3-substituted phthalides. Ray and coworkers $^{89}$ carried out chiral Brønsted acid $\mathbf{1 4 0}$ catalyzed, tandem mannich-lactamization, and aldol-lactonization reactions to achieve the enantioselective synthesis of phthalides $\mathbf{1 4 3}$ in good to excellent enantioselectivities (Scheme 26). The developed protocol has broad substrate scope, and a variety of substituted aromatic aldehydes and aromatic amine were used. 


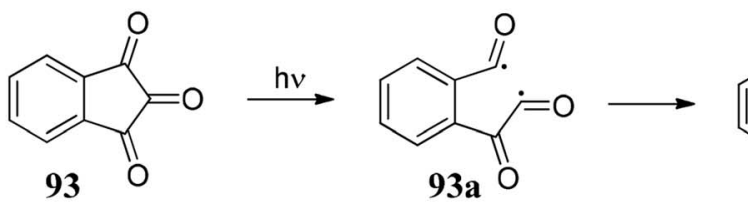<smiles>O=CC1([O-])C(=O)c2ccccc21</smiles><smiles></smiles>

93c<smiles>C[13CH3]</smiles><smiles>[R]OC</smiles>

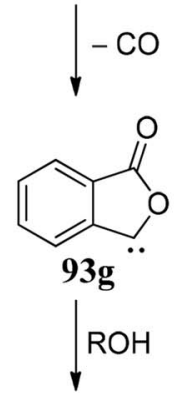<smiles>[R]OC(=O)C1(O)C(=O)c2ccccc21</smiles><smiles>[R]OC1OC(=O)c2ccccc21</smiles>

95<smiles>[R]OC[C@H]1OC(=O)c2ccccc21</smiles><smiles>[3H][13CH3]</smiles><smiles>[R]OC(=O)C1OC(=O)c2ccccc21</smiles>

94

Scheme 15 Proposed mechanistic pathway.

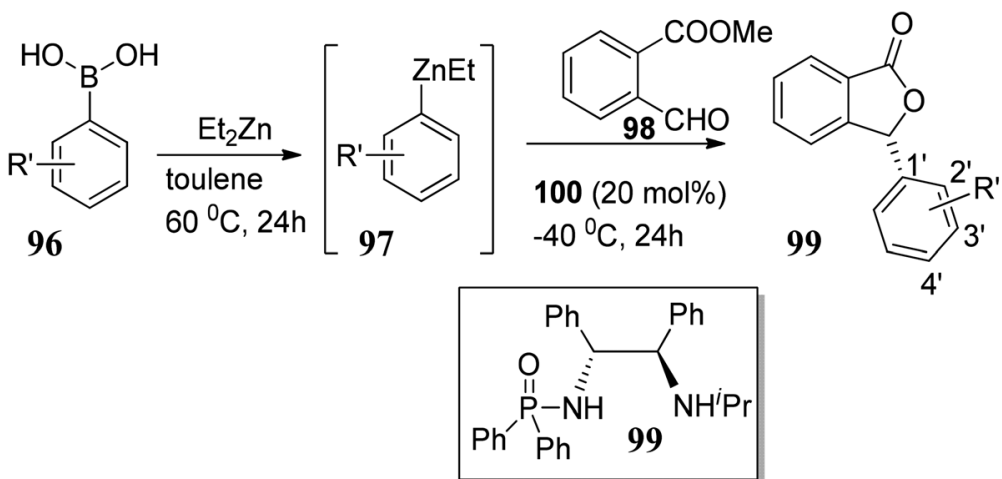

$\mathrm{R}^{\prime}=2 '-\mathrm{H} ; 91 \%$ yield $(82 \%$ ee $)$

$\mathrm{R}^{\prime}=2 '-\mathrm{Me} ; 85 \%$ yield $(76 \% \mathrm{ee})$

$\mathrm{R}^{\prime}=3{ }^{\prime}-\mathrm{Me} ; 95 \%$ yield $(74 \% \mathrm{ee})$

$\mathrm{R}^{\prime}=4{ }^{\prime}-\mathrm{Me} ; 83 \%$ yield $(73 \%$ ee $)$

$\mathrm{R}^{\prime}=3^{\prime}-\mathrm{Cl} ; 81 \%$ yield $(87 \%$ ee)

$\mathrm{R}^{\prime}=4{ }^{\prime}-\mathrm{Cl} ; 82 \%$ yield $(78 \%$ ee)

$\mathrm{R}^{\prime}=3^{\prime}-\mathrm{OMe} ; 85 \%$ yield $(84 \% \mathrm{ee})$

$\mathrm{R}^{\prime}=4{ }^{\prime}-\mathrm{OMe} ; 84 \%$ yield $(80 \% \mathrm{ee})$

$\mathrm{R}^{\prime}=4^{\prime}-\mathrm{F} ; 86 \%$ yield $(86 \%$ ee)

Scheme 16 Asymmetric 1,2-addition/lactonization tandem reaction of methyl 2-formylbenzoate.

\section{Application of 3-substituted $1(3 H)$ - isobenzofuranones for the construction of crucial molecular architecture}

As discussed in Table 1, we can state that phthalide moiety is present in various biologically active natural products. In this section, we aim to provide some of the examples of 3- substituted 1(3H)-isobenzofuranones for the construction of important molecular architecture.

\subsection{Annulation of stabilized phthalide anions with Michael acceptors}

Annulation with stabilized phthalide anions along with Michael acceptors is a powerful and convenient tool for obtaining the quinoid natural products. Many natural products consist of a standard quinone unit. The exciting structures and vital 
<smiles>COC(=O)c1ccccc1C=O</smiles>
$\mathrm{RB}(\mathrm{OH})_{2}, \mathrm{Et}_{2} \mathrm{Zn}$
$103(20 \mathrm{~mol} \%)$ toluene, $-5^{\circ} \mathrm{C}, 5 \mathrm{~h}$ 2-formylbenzoate 101<smiles>[R]C1OC(=O)c2ccccc21</smiles>

3-aryl phthalide 102<smiles>Cc1ccccc1[C@H](NC(C)c1ccccc1)c1c(O)ccc2ccccc12</smiles>

$\mathrm{R}=\mathrm{Ph}, 80 \%$ yield $(91 \%$ ee $)$

$\mathrm{R}=0$-tolyl, $86 \%$ yield $(83 \%$ ee $)$

$\mathrm{R}=p$-tolyl, $90 \%$ yield $(91 \% \mathrm{ee})$

$\mathrm{R}=4-\mathrm{PhC}_{6} \mathrm{H}_{4}, 71 \%$ yield $(81 \%$ ee $)$

$\mathrm{R}=4-\mathrm{ClC}_{6} \mathrm{H}_{4}, 58 \%$ yield $(85 \%$ ee)

$\mathrm{R}=4-\mathrm{BrC}_{6} \mathrm{H}_{4}, 95 \%$ yield $(83 \%$ ee)

$\mathrm{R}=4-\mathrm{MeOC}_{6} \mathrm{H}_{4}, 71 \%$ yield $(91 \%$ ee $)$

Scheme 17 Asymmetric arylation-lactonization sequence.<smiles>[R18]Nc1c[R]#ccc1C(=O)OC</smiles>

104<smiles>[C+]1=COCC1</smiles>

105
$\mathrm{Pd}_{2}(\mathrm{dba})_{3}(5 \mathrm{~mol} \%)$ PyraBox (10 mol \%) $\mathrm{CaCO}_{3}$ (2 equiv.) $\mathrm{THF} / \mathrm{H}_{2} \mathrm{O}(99: 1)$, r.t.<smiles>[R]C=C(C(=O)OC)c1cc[R]([H])cc1</smiles>

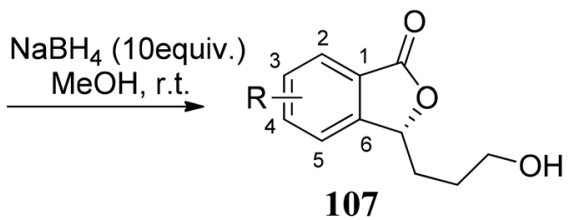

107

$\mathrm{R}=2-\mathrm{Me} ; 66 \%$ yield $\left(99 \%\right.$ ee); $\mathrm{R}=3-\mathrm{OMe} ; 62 \%$ yield $\left(98 \%\right.$ ee); $\mathrm{R}=3-\mathrm{NO}_{2} ; 55 \%$ yield $(98.5 \%$ ee);

$\mathrm{R}=3-\mathrm{Cl} ; 60 \%$ yield $\left(98.5 \%\right.$ ee); $\mathrm{R}=3-\mathrm{Br} ; 55 \%$ yield $\left(98.5 \%\right.$ ee); $\mathrm{R}=3-\mathrm{Br} \& 4{ }^{i} \mathrm{Pr} ; 58 \%$ yield $(98.5 \%$ ee);

$\mathrm{R}=3-\mathrm{OMe} \& 4-\mathrm{OMe} ; 56 \%$ yield $(98.5 \%$ ee); $\mathrm{R}=2-\mathrm{OMe} \& 4-\mathrm{OMe} ; 58 \%$ yield $(98.5 \%$ ee)

Scheme 18 Heck-Matsuda arylation of dihydrofurans.<smiles>[R]C=C1OC(=O)c2ccccc21</smiles>

108 R'
$(R, S)-110(1 \mathrm{~mol} \%)$ $\mathrm{H}_{2},(10 \mathrm{~atm})$ $\mathrm{CH}_{2} \mathrm{Cl}_{2}, \mathrm{rt}, 24 \mathrm{~h}$

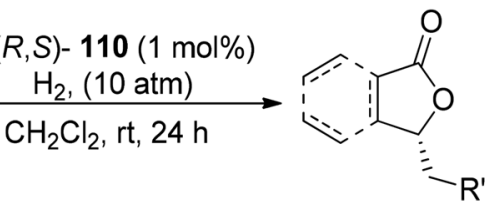
109

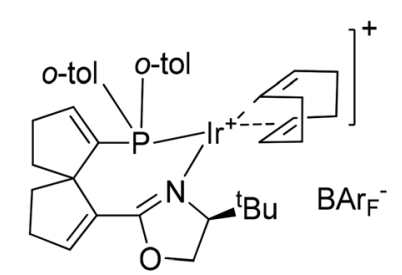

SpinPHOX-Ir (110)
$\mathrm{R}^{\prime}={ }^{\mathrm{n}} \mathrm{Bu} ; 98 \%$ yield $(95 \%$ ee $)$

$\mathrm{R}^{\prime}=\mathrm{Me} ; 86 \%$ yield $(86 \% \mathrm{ee})$

$\mathrm{R}^{\prime}=\mathrm{Et} ; 93 \%$ yield $(96 \%$ ee)

$\mathrm{R}^{\prime}={ }^{\mathrm{n}} \mathrm{Pr} ; 98 \%$ yield $(95 \% \mathrm{ee})$

$\mathrm{R}^{\prime}={ }^{\mathrm{n}}$ Pentyl; $94 \%$ yield $(91 \%$ ee $)$

$\mathrm{R}^{\prime}=\mathrm{C}_{6} \mathrm{H}_{5} ; 100 \%$ yield $(97 \%$ ee)

$\mathrm{R}^{\prime}=$ Napthalene; $98 \%$ yield $(94 \%$ ee $)$

$\mathrm{R}^{\prime}=$ Thiophene; $40 \%$ yield (95\% ee)

Scheme 19 Asymmetric hydrogenation of the 3-alkyl/arylidenephthalides.<smiles>[R]CC(=O)C1=C(C(=O)OCC)C=C[R]([R])C=C1</smiles>

$\left[\mathrm{RuCl}_{2}(p \text {-cymene })\right]_{2} / 113$ $\mathrm{HCOONa}, 4 \% \mathrm{CTAB}$ $\mathrm{H}_{2} \mathrm{O} / \mathrm{DCM}, 40^{\circ} \mathrm{C}$

(90-99\%)<smiles>[R]CC1OC(=O)c2ccc([R])cc21</smiles>
upto $99 \%$ ee

( $C T A B=$ cetyltrimethylammonium bromide)

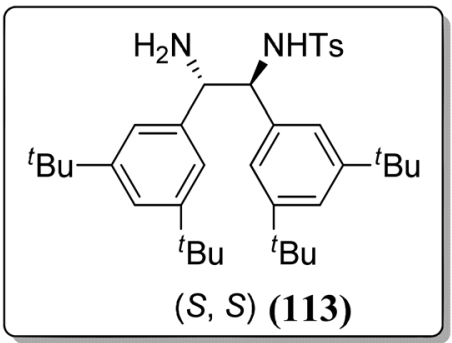

$\mathrm{R}=\mathrm{R}^{1}=\mathrm{H} ; 97 \%$ yield $(98 \%$ ee $)$

$\mathrm{R}=\mathrm{Me}, \mathrm{R}^{1}=\mathrm{H} ; 95 \%$ yield $(98 \% \mathrm{ee})$

$\mathrm{R}=\mathrm{ClCH}_{2}\left(\mathrm{CH}_{2}\right)_{2}, \mathrm{R}^{1}=\mathrm{H} ; 95 \%$ yield $(99 \%$ ee $)$

$\mathrm{R}=\mathrm{Ph}, \mathrm{R}^{1}=\mathrm{H} ; 96 \%$ yield $(99 \% \mathrm{ee})$

$\mathrm{R}=4-\mathrm{ClC}_{6} \mathrm{H}_{4}, \mathrm{R}^{1}=\mathrm{H} ; 98 \%$ yield $(99 \%$ ee $)$

$\mathrm{R}=4-\mathrm{MeC}_{6} \mathrm{H}_{4}, \mathrm{R}^{1}=\mathrm{H} ; 93 \%$ yield $(99 \%$ ee $)$

$\mathrm{R}=4-\mathrm{MeOC}_{6} \mathrm{H}_{4}, \mathrm{R}^{1}=\mathrm{H} ; 96 \%$ yield $(99 \%$ ee)

$\mathrm{R}=4-\mathrm{MeSC}_{6} \mathrm{H}_{4}, \mathrm{R}^{1}=\mathrm{H} ; 99 \%$ yield $(99 \%$ ee)

$\mathrm{R}=4-\mathrm{CF}_{3} \mathrm{C}_{6} \mathrm{H}_{4}, \mathrm{R}^{1}=\mathrm{H} ; 96 \%$ yield $(99 \%$ ee $)$
$\mathrm{R}=3,5-(\mathrm{MeO})_{2} \mathrm{C}_{6} \mathrm{H}_{3}, \mathrm{R}^{1}=\mathrm{H} ; 93 \%$ yield $(99 \%$ ee

$\mathrm{R}=2$-thienyl, $\mathrm{R}^{1}=\mathrm{H} ; 97 \%$ yield (99\% ee)

$\mathrm{R}=1$-napthyl, $\mathrm{R}^{1}=\mathrm{H} ; 98 \%$ yield $(99 \% \mathrm{ee})$

$\mathrm{R}=4$-quinolyl, $\mathrm{R}^{1}=\mathrm{H} ; 94 \%$ yield $(98 \% \mathrm{ee})$

$\mathrm{R}=4$-Cl-phenoxyl, $\mathrm{R}^{1}=\mathrm{H} ; 94 \%$ yield (99\% ee)

$\mathrm{R}=4-\mathrm{Cl}$-phenylthio, $\mathrm{R}^{1}=\mathrm{H} ; 97 \%$ yield $(98 \%$ ee)

$\mathrm{R}=\mathrm{Ph}, \mathrm{R}^{1}=4-\mathrm{Br} ; 90 \%$ yield $(99 \%$ ee $)$

$\mathrm{R}=\mathrm{Ph}, \mathrm{R}^{1}=5-\mathrm{Br} ; 93 \%$ yield $(99 \% \mathrm{ee})$

$\mathrm{R}=\mathrm{Ph}, \mathrm{R}^{1}=4,5-\mathrm{Cl}_{2} ; 98 \%$ yield $(98 \%$ ee $)$

$\mathrm{R}=\mathrm{Ph}, \mathrm{R}^{1}=4,5-\mathrm{C}_{6} \mathrm{H}_{4} ; 97 \%$ yield $(98 \%$ ee $)$

Scheme 20 Asymmetric synthesis of 3-substituted phthalides by ruthenium-catalyzed transfer hydrogenation. 


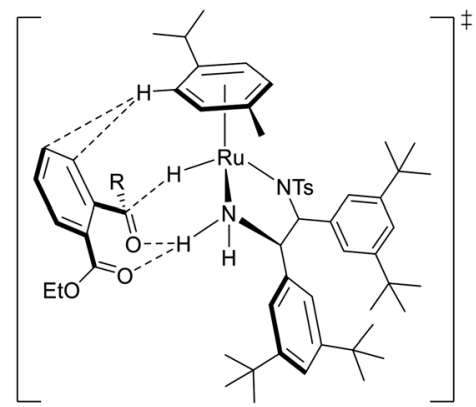

Fig. 6 Proposed transition state.

biological activities ${ }^{90}$ of these natural products have provided an influential forum for organic chemists to explore this area of research. The general protocol for this reaction was discovered in the late 1970s simultaneously by Hauser ${ }^{91}$ and Kraus. ${ }^{92}$

The phthalide annulation involves the deprotonation of a stabilized phthalides 144 by a strong base and in situ capture of anion by a suitable Michael acceptor 145 followed by Dieckmannlike condensation to afford a bicyclic compound 148 (Scheme
27). Compound 148 undergoes mild oxidation to form biphenol derivatives 149. This methodology presents an elegant way to synthetic naphthol derivatives via phthalide chemistry.

Chaturvedi and co-workers ${ }^{93}$ developed a novel route to utilize unsaturated phosphonates for annulation reaction as Hauser acceptors. Good yields of phosphorylated 1,4-dihydroxynaphthalenes 153 are obtained, which on further oxidation results in their corresponding 1,4-naphthoquinones 154. The reaction is successful in providing an efficient, straightforward, and powerful approach for synthesizing disubstituted naphthalene-1,4-diols 153. Naphtha-1,4-diones 154 consist of a various (hetero) aryl groups positioned at 3 and a phosphonate group positioned at 2 (Scheme 28).

4.1.1 Metal-free catalytic annulation to develop enantioriched highly functionalized dihydronaphthoquinones. A metalfree catalytic annulation is developed by Zhuang and coworkers, ${ }^{\mathbf{9 4}}$ which involves Lewis base-mediated asymmetric allylic alkylation and a novel asymmetric intramolecular acyl cyanation of alkenes. This route provides a novel method to obtain enantioriched highly functionalized dihydronaphthoquinones 160 and chiral 3,3-disubstituted phthalides 158 having quaternary<smiles></smiles>

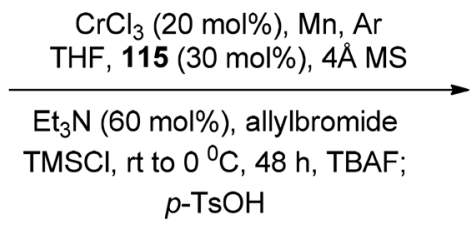

$\mathrm{R}^{1}=\mathrm{H}, \mathrm{R}^{2}=\mathrm{OCH}_{3}, \mathrm{R}^{3}=\mathrm{H}, \mathrm{R}^{4}=\mathrm{OCH}_{3} ; 87 \%$ yield $(97 \%$ ee $)$

$\mathrm{R}^{1}=\mathrm{H}, \mathrm{R}^{2}=\mathrm{OCH}_{3}, \mathrm{R}^{3}=\mathrm{OCH}_{3}, \mathrm{R}^{4}=\mathrm{H} ; 85 \%$ yield $(94 \%$ ee $)$

$\mathrm{R}^{1}=\mathrm{OCH}_{3}, \mathrm{R}^{2}=\mathrm{OCH}_{3}, \mathrm{R}^{3}=\mathrm{OCH}_{3}, \mathrm{R}^{4}=\mathrm{H} ; 89 \%$ yield $(99 \%$ ee $)$

$\mathrm{R}^{1}=\mathrm{H}, \mathrm{R}^{2}=\mathrm{H}, \mathrm{R}^{3}=\mathrm{H}, \mathrm{R}^{4}=\mathrm{H} ; 86 \%$ yield $(96 \%$ ee $)$

$\mathrm{R}^{1}=\mathrm{H}, \mathrm{R}^{2}=\mathrm{H}, \mathrm{R}^{3}=\mathrm{OCH}_{3}, \mathrm{R}^{4}=\mathrm{H} ; 90 \%$ yield $(97 \%$ ee $)$

$\mathrm{R}^{1}=\mathrm{H}, \mathrm{R}^{2}=\mathrm{H}, \mathrm{R}^{3}=\mathrm{N}\left(\mathrm{CH}_{3}\right)_{2}, \mathrm{R}^{4}=\mathrm{H} ; 70 \%$ yield $(96 \%$ ee $)$

$\mathrm{R}^{1}=\mathrm{H}, \mathrm{R}^{2}=\mathrm{Br}, \mathrm{R}^{3}=\mathrm{N}\left(\mathrm{CH}_{3}\right)_{2}, \mathrm{R}^{4}=\mathrm{H} ; 90 \%$ yield $(98 \%$ ee $)$<smiles>[R]c1c([R])c([R1])c2c(c1[Z10])C(=O)O[C@H]2CC=C</smiles>

116

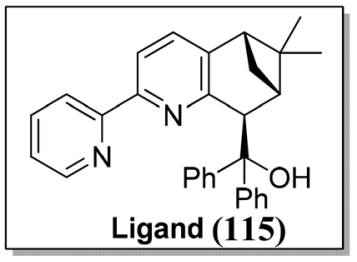

Scheme 21 Enantioselective Nozaki-Hiyama-Kishi allylation.<smiles>[R]C(=O)c1cc2ccccc2cc1C([R])=O</smiles>

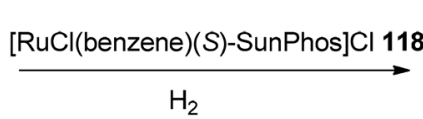
117

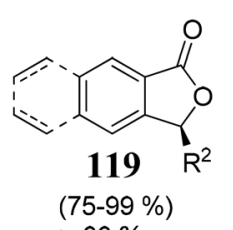

$>99 \%$ ee

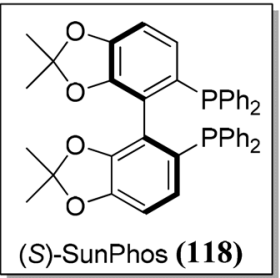

$\mathrm{R}^{1}=\mathrm{Me}, \mathrm{R}^{2}=\mathrm{C}_{6} \mathrm{H}_{5} ; 95 \%$ yield $(98.2 \%$ ee $)$

$\mathrm{R}^{1}=\mathrm{H}, \mathrm{R}^{2}=\mathrm{C}_{6} \mathrm{H}_{5} ; 95 \%$ yield $(96.2 \%$ ee $)$

$\mathrm{R}^{1}=\mathrm{Me}, \mathrm{R}^{2}=0-\mathrm{CH}_{3} \mathrm{C}_{6} \mathrm{H}_{4} ; 75 \%$ yield $(99.2 \%$ ee)

$\mathrm{R}^{1}=\mathrm{Me}, \mathrm{R}^{2}=p-\mathrm{CH}_{3} \mathrm{C}_{6} \mathrm{H}_{4} ; 87 \%$ yield $(33.8 \%$ ee $)$

$\mathrm{R}^{1}=\mathrm{Me}, \mathrm{R}^{2}=0-\mathrm{CF}_{3} \mathrm{C}_{6} \mathrm{H}_{4} ; 98 \%$ yield $(99.4 \%$ ee $)$

Methyl 2-acetyl-5-methylbenzoate; $98 \%$ yield $(99.0 \%$ ee)

Methyl 2-acetyl-5-chlorolbenzoate; $98 \%$ yield $(99.4 \%$ ee)

Methyl 3-acetyl-2-napthoate; $98 \%$ yield $(99.4 \%$ ee)

Scheme 22 Asymmetric hydrogenation of 2-acylarylcarboxylate. 
<smiles>[R]C=Cc1cc([R])c([R])c([R1])c1C=O</smiles>

120
$121(20 \mathrm{~mol} \%)$ $122(40 \mathrm{~mol} \%)$ toluene $(0.05 \mathrm{M})$ air, $80{ }^{\circ} \mathrm{C}(55-90 \%)$<smiles>[R]C[C@H]1OC(=O)c2c1cc([R3])c([R])c2[R]</smiles>

123

er upto $92: 8$

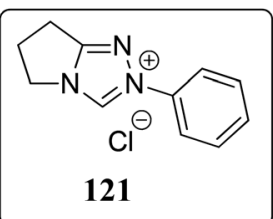

121

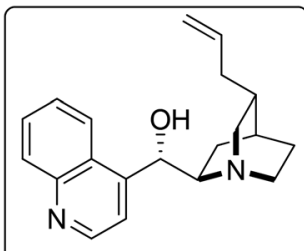

Cinchonine 122

$\mathrm{R}^{1}=\mathrm{R}^{2}=\mathrm{R}^{3}=\mathrm{H}, \mathrm{R}^{4}=\mathrm{CO}_{2} \mathrm{Et} ; 72 \%$ yield $(96 \%$ ee $) \quad \mathrm{R}^{1}=\mathrm{R}^{2}=\mathrm{R}^{3}=\mathrm{H}, \mathrm{R}^{4}=\mathrm{PO}(\mathrm{OEt})_{2} ; 90 \%$ yield $(94 \%$ ee $)$

$R^{1}=R^{2}=R^{3}=H, R^{4}=\mathrm{CO}_{2} \mathrm{Me} ; 70 \%$ yield $(95 \%$ ee $) \quad: R^{1}=R^{2}=H, R^{3}=M e, R^{4}=C_{2}$ Et; $75 \%$ yield $(95.5 \%$ ee $)$ $\begin{array}{ll:l}\mathrm{R}^{1}=\mathrm{R}^{2}=\mathrm{R}^{3}=\mathrm{H}, \mathrm{R}^{4}=\mathrm{CO}_{2}{ }^{n} \mathrm{Bu} ; 71 \% \text { yield }(95.5 \% \text { ee }) & \left.\mathrm{R}^{1}=\mathrm{R}^{2}=\mathrm{H}, \mathrm{R}^{3}=\mathrm{Me}, \mathrm{R}^{4}=\mathrm{CO}_{2} \mathrm{Et} ; 75 \% \text { yield (95.5\% ee }\right) \\ \mathrm{R}^{1}=\mathrm{R}^{2}=\mathrm{R}^{3}=\mathrm{H}, \mathrm{R}^{4}=\mathrm{CO}_{2}{ }^{t} \mathrm{Bu} ; 71 \% \text { yield }(96.5 \% \text { ee }) & \left.\mathrm{R}^{2}=\mathrm{OMe}, \mathrm{R}^{3}=\mathrm{H}, \mathrm{R}^{4}=\mathrm{CO}_{2}{ }^{t} \mathrm{Bu} ; 70 \% \text { yield (95.5\% ee }\right)\end{array}$ $\begin{array}{l:l}\mathrm{R}^{1}=\mathrm{R}^{2}=\mathrm{R}^{3}=\mathrm{H}, \mathrm{R}^{4}=\mathrm{CO}_{2}{ }^{t} \mathrm{Bu} ; 71 \% \text { yield }(96.5 \% \text { ee) }) & \mathrm{R}^{1}=\mathrm{H}, \mathrm{R}^{2}=\mathrm{OMe}, \mathrm{R}^{3}=\mathrm{H}, \mathrm{R}^{4}=\mathrm{CO}_{2}{ }^{t} \mathrm{Bu} ; 70 \% \text { yield (95.5\% ee) } \\ \mathrm{R}^{1}=\mathrm{R}^{2}=\mathrm{R}^{3}=\mathrm{H}, \mathrm{R}^{4}=\mathrm{CN} ; 55 \% \text { yield }(90.5 \% \text { ee }) & \mathrm{O}^{2}, \mathrm{R}^{3}=\mathrm{OMe}, \mathrm{R}^{4}=\mathrm{CO}_{2} \mathrm{Et} ; 63 \% \text { yield (94.5\% ee }\end{array}$ $R^{1}=R^{2}=R^{3}=H, R^{4}=$ COMe $; 72 \%$ yield $(75.5 \%$ ee $)$

$\mathrm{R}^{1}=\mathrm{OMe}, \mathrm{R}^{2}=\mathrm{H}, \mathrm{R}^{3}=\mathrm{OMe}, \mathrm{R}^{4}=\mathrm{CO}_{2} \mathrm{Me} ; 74 \%$ yield $(96 \%$ ee $)$

Scheme 23 Asymmetric oxidative cyclization of 2-alkenylbenzaldehydes.

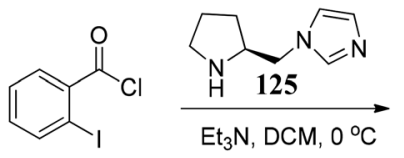

124<smiles>O=C(c1ccccc1I)N1CCCN1CCn1ccnc1</smiles>

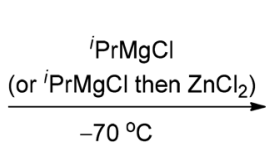

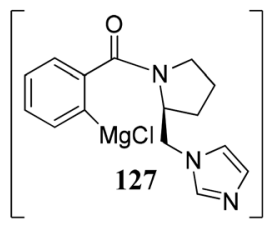

128 $\mathrm{RCHO}$, then $\mathrm{H}_{3} \mathrm{O}^{+}$<smiles>O=C(O)c1ccccc1C(=O)N1CCCN1CCn1ccnc1</smiles>

$p$-TsOH, toluene, reflux<smiles>[R]C1OC(=O)c2ccccc21</smiles>

130

$$
\begin{aligned}
& \mathrm{R}=\mathrm{Ph} ; 70 \% \text { yield }(88 \% \text { ee }) \\
& \mathrm{R}=2-\mathrm{Cl}-\mathrm{C}_{6} \mathrm{H}_{4} ; 67 \% \text { yield }(82 \% \text { ee }) \\
& \mathrm{R}=4-\mathrm{Br}-\mathrm{C}_{6} \mathrm{H}_{4} ; 67 \% \text { yield }(88 \% \text { ee }) \\
& \mathrm{R}=2-\mathrm{Me}-\mathrm{C}_{6} \mathrm{H}_{4} ; 63 \% \text { yield }(86 \% \text { ee }) \\
& \mathrm{R}=4-\mathrm{Me}-\mathrm{C}_{6} \mathrm{H}_{4} ; 64 \% \text { yield }(88 \% \text { ee }) \\
& \mathrm{R}=4-\mathrm{Cl}-\mathrm{C}_{6} \mathrm{H}_{4} ; 65 \% \text { yield }(88 \% \mathrm{ee}) \\
& \mathrm{R}={ }^{\mathrm{n}} \mathrm{Pr} ; 65 \% \text { yield }(80 \% \mathrm{ee}) \\
& \mathrm{R}={ }^{\mathrm{i}} \mathrm{Pr} ; 62 \% \text { yield }(77 \% \text { ee }) \\
& \mathrm{R}={ }^{\mathrm{t}} \mathrm{Bu} ; 60 \% \text { yield }(66 \% \text { ee })
\end{aligned}
$$

Scheme 24 Direct asymmetric synthesis of 3-substituted phthalides.

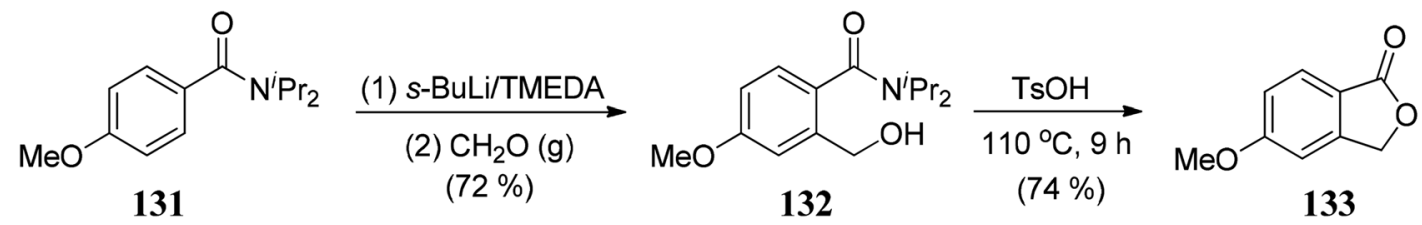

(1) KHMDS, THF/Et $2 \mathrm{O}(2: 1)$

(2)

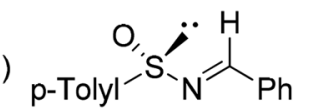

(S)

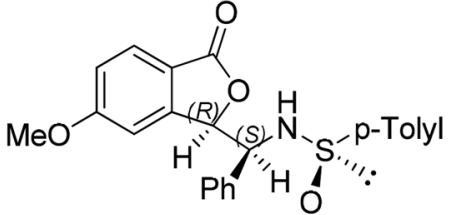

135<smiles>[2H]C(C)(O)[C@@]1(c2ccccc2)OC(=O)c2ccc(OC)cc21</smiles>

136

Scheme 25 Reaction of phthalide anion with enantiopure sulfinimines. 
<smiles>CC(=O)c1ccccc1C=O</smiles>

137<smiles>CCOC(=O)C(=N)Oc1ccc(N)cc1</smiles>

138<smiles>CCOC(=N)[C@H]1OC(=O)c2ccccc21</smiles>

$140(5 \mathrm{~mol} \%), \mathrm{DCM}$
$\underset{4 \mathrm{~A} \mathrm{MS},-20^{\circ} \mathrm{C}, 36 \mathrm{~h}}{\stackrel{96 \%(95 \% \text { ee })}{\longrightarrow}}$ 139
141
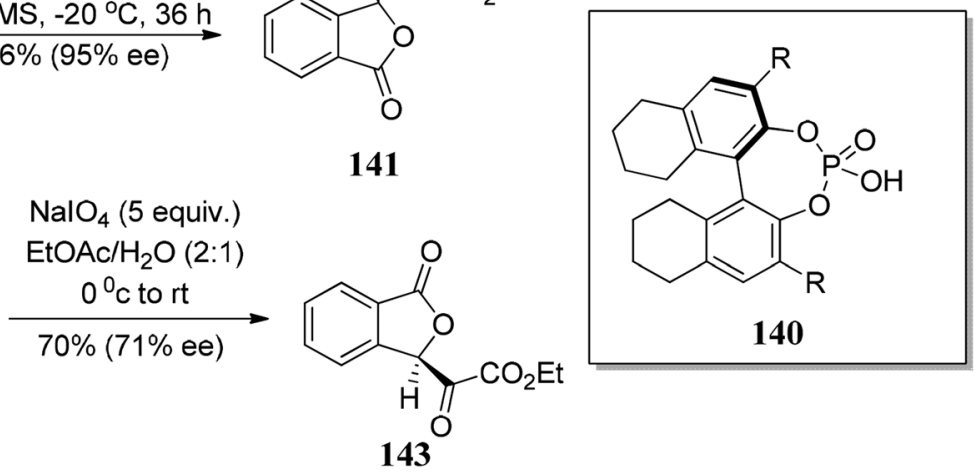

143
142<smiles>CCOC(=NN)[C@H]1OC(=O)c2ccccc21</smiles>
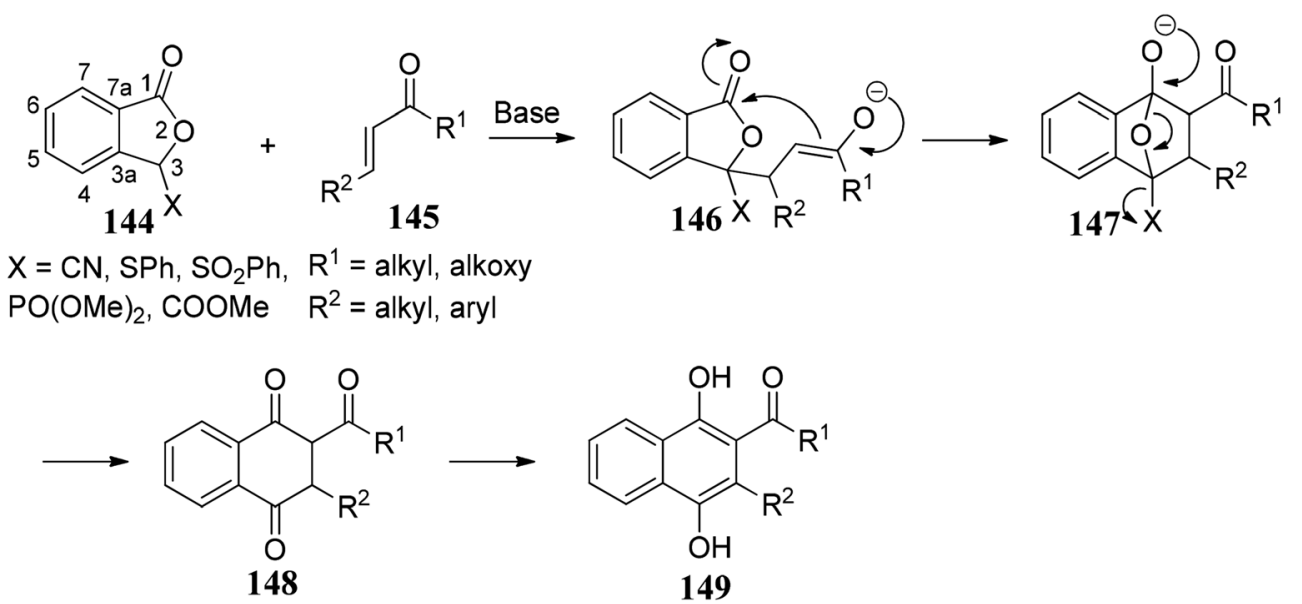

Scheme 27 Annulation of stabilized phthalide anions with Michael acceptors.

carbon centers (Schemes 29 and 30). The reaction involves the use of chiral bifunctional thiourea organocatalyst.

4.1.2 Hauser-Kraus annulation to give naphthoquinolcarbohydrate hybrids. Chakraborty and co-workers ${ }^{95}$ described a regioselective approach to naphthoquinone/naphthoquinolcarbohydrate hybrids using 3-cyano phthalides $\mathbf{1 6 1}$ as one of the essential precursors. In this approach, anionic annulation of 3cyano phthalides 161 takes place with an acrylate appended sugar moiety 162 (Scheme 31).

4.1.3 Total synthesis of uncialamycin via Hauser-Kraus annulation. Nicolaou and co-workers ${ }^{96}$ described the total synthesis of uncialamycin, and a Hauser-Kraus annulation was employed as one of the critical reactions for the synthesis of uncialamycin core (Scheme 32).

4.1.4 Total synthesis of the griseusin B scaffold (bioactive natural product) via Hauser-Kraus annulation. Naysmith and co-workers ${ }^{97}$ developed a convergent route for the synthesis of the griseusin B scaffold (bioactive natural product). The main steps of the synthetic journey include the highly effective onepot Hauser-Kraus annulation followed by methylation and double deprotection-spirocyclization sequence that directly results in the target tetracyclic ring system (Scheme 33).

\subsection{Total synthesis of $(-)-\alpha$-noscapine}

$(-)-\alpha$-Noscapine (narcotine), which was initially isolated from Papaver somniferum L., ${ }^{98}$ is a non-addictive anti-tussive agent with little to no significant toxicity. ${ }^{99}(-)-\alpha$-noscapine also displays other probable scientific utilities ${ }^{100}$ for the treatment of life-threating diseases. Naturally occurring noscapine consists of two adjacent chiral centers: one at C- $5^{\prime}$ position of tetrahydroisoquinoline ring and another at the $\mathrm{C}-3$ position of phthalide framework.

$\mathrm{Xu}$ and co-workers ${ }^{101}$ commenced with the synthesis of meconine-3-carboxylic acid 173, which could be synthesized from pure 2,3-dimethoxybenzoic acid $\mathbf{1 7 1}$ and glyoxylic acid $\mathbf{1 7 2}$ in the presence of a conc. $\mathrm{H}_{2} \mathrm{SO}_{4}$. While the amine functionality 174 could be easily prepared from gallic acid over a nine-step sequence. The amide bond ( $\mathrm{C}^{\prime}-\mathrm{C} 3$ bond formation) was formed from the acyl chloride derivative of $\mathbf{1 7 3}$ and free amine $\mathbf{1 7 4}$ to give compound $\mathbf{1 7 5}$ in $\mathbf{8 9 \%}$ yield (Scheme 34). The next step of the sequence was Bischler-Napieralski reaction in the 
<smiles>[R][R]1ccc2c(c1)C(Br)OC2=O</smiles>

$\mathrm{Bt}=$ Benzotriaole 150
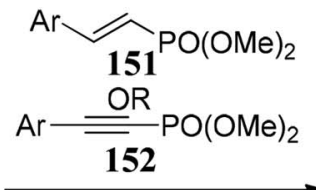

LiHMDS, THF

$-78{ }^{\circ} \mathrm{C}, 60-90 \mathrm{~min}$

(upto $78 \%$ )<smiles>[R]Oc1c(O)c(O)c2cc[R][c-]c2c1OC(C)=O</smiles>

153

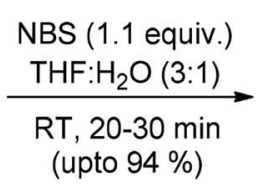

$\mathrm{RT}, 20-30 \mathrm{~min}$
(upto $94 \%$ )<smiles>[R][X]=C1C(=O)c2ccc(OC)cc2C(=O)C1=[Bi]</smiles>

154

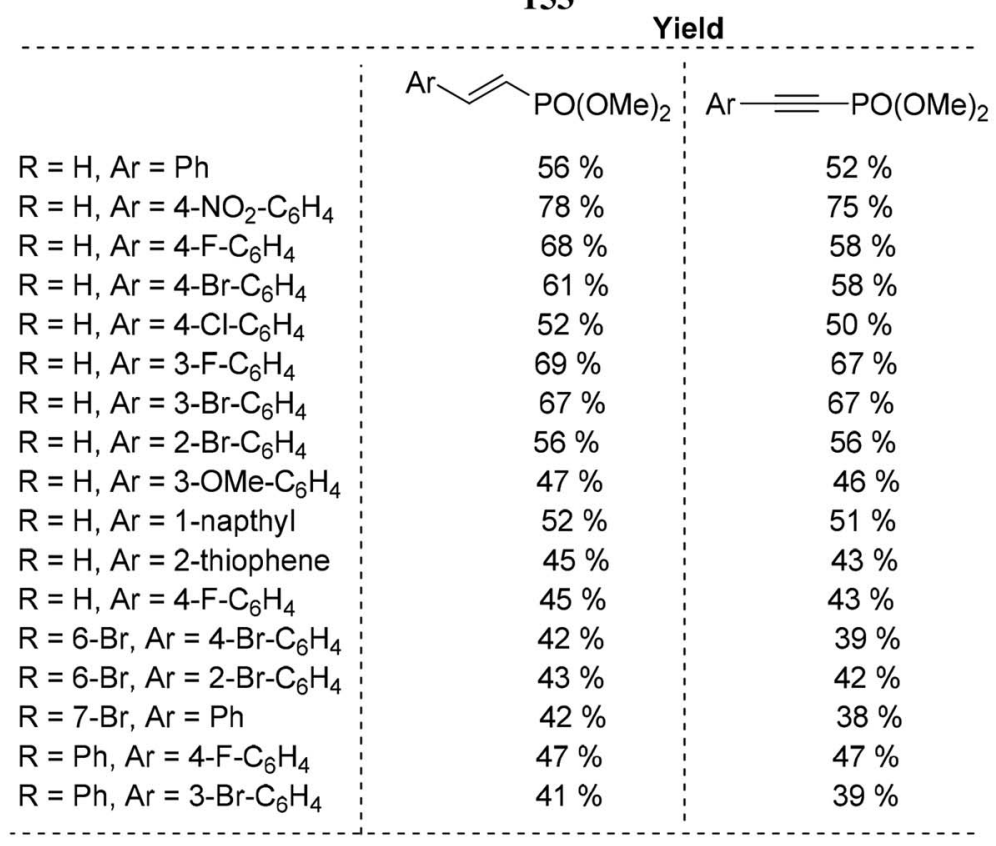

Scheme 28 Hauser-Kraus annulation of 3-substituted phthalides.

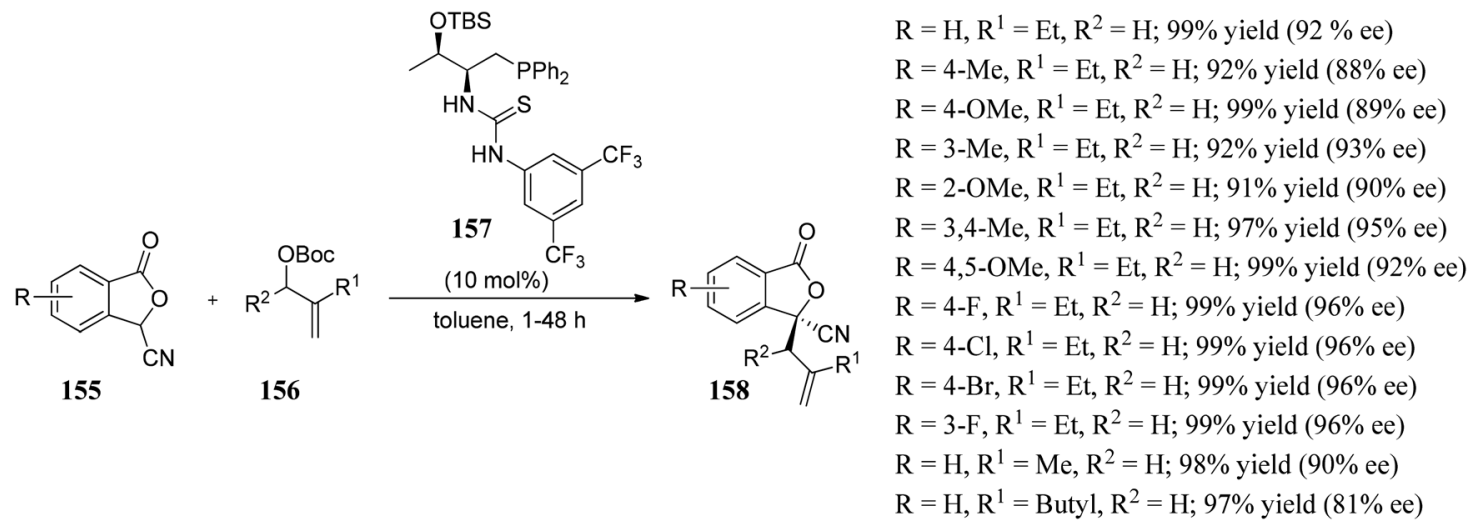

Scheme 29 Lewis base-catalyzed asymmetric allylic alkylation of 3-cyano phthalides.

presence of $\mathrm{POCl}_{3}$. The cyclization took place efficiently to give imine, which was further reduced to afford tetrahydroisoquinoline 176. After extensive optimization of $\mathrm{NaBH}_{4} /$ $\mathrm{NaBH}_{3} \mathrm{CN}$ mediated reduction, it was concluded that low reaction temperature was critical for the high diastereoselectivity and moderately high yields. Subsequently, Eschweiler-Clarke reaction was used to obtain an $N$-methylated compound, 177 in $75 \%$ yield. RANEY® Ni was used for hydrogenation of 177 to produce target compound $\mathbf{8}$. Further recrystallization of the crude sample gave pure $( \pm)-\alpha$-noscapine $\mathbf{8}$.

\subsection{Total synthesis of olaparib}

Olaparib is an FDA approved targeted therapy for the treatment of cancer. It is a PARP inhibitor, inhibiting poly ADP ribose polymerase (PARP), an enzyme that plays a role in DNA repair. It targets 
<smiles>[R][Y]1ccc2c(c1)C(=O)O[C@]2(N)C([R])C(=C)C(=O)OCC</smiles>

$$
\begin{aligned}
& \mathrm{R}=\mathrm{H}, \mathrm{R}^{2}=\mathrm{H} ; 71 \% \text { yield }(95 \% \text { ee }) \\
& \mathrm{R}=4-\mathrm{Me}, \mathrm{R}^{2}=\mathrm{H} ; 67 \% \text { yield }(97 \% \text { ee }) \\
& \mathrm{R}=4-\mathrm{OMe}, \mathrm{R}^{2}=\mathrm{H} ; 55 \% \text { yield }(99 \% \text { ee }) \\
& \mathrm{R}=3-\mathrm{Me}, \mathrm{R}^{2}=\mathrm{H} ; 52 \% \text { yield }(86 \% \text { ee }) \\
& \mathrm{R}=3,4-\mathrm{Me}, \mathrm{R}^{2}=\mathrm{H} ; 64 \% \text { yield }(95 \% \text { ee }) \\
& \mathrm{R}=4,5-\mathrm{OMe}, \mathrm{R}^{2}=\mathrm{H} ; 55 \% \text { yield }(59 \% \text { ee }) \\
& \mathrm{R}=2-\mathrm{OMe}, \mathrm{R}^{2}=\mathrm{H} ; 52 \% \text { yield }(52 \% \text { ee }) \\
& \mathrm{R}=4-\mathrm{F}, \mathrm{R}^{2}=\mathrm{H} ; 48 \% \text { yield }(95 \% \text { ee }) \\
& \mathrm{R}=4-\mathrm{Cl}, \mathrm{R}^{2}=\mathrm{H} ; 47 \% \text { yield }(86 \% \text { ee }) \\
& \mathrm{R}=4-\mathrm{Br}, \mathrm{R}^{2}=\mathrm{H} ; 48 \% \text { yield }(83 \% \text { ee }) \\
& \mathrm{R}=3-\mathrm{F}, \mathrm{R}^{2}=\mathrm{H} ; 48 \% \text { yield }(83 \% \text { ee })
\end{aligned}
$$

Scheme 30 Annulation reaction of 3-substituted phthalides.
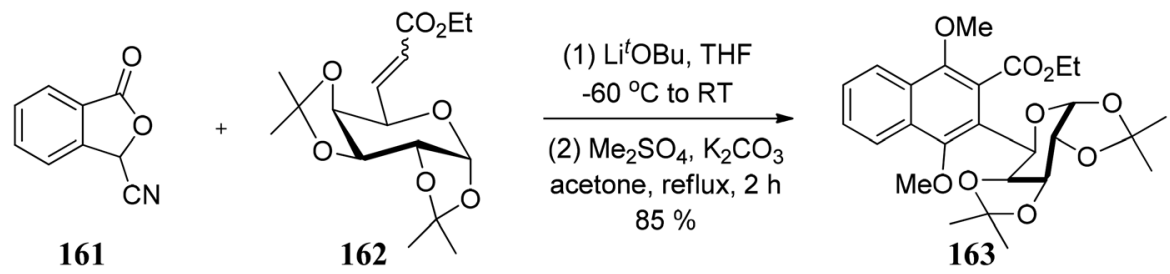

Scheme 31 Hauser-Kraus annulation to give naphthoquinol-carbohydrate hybrids.

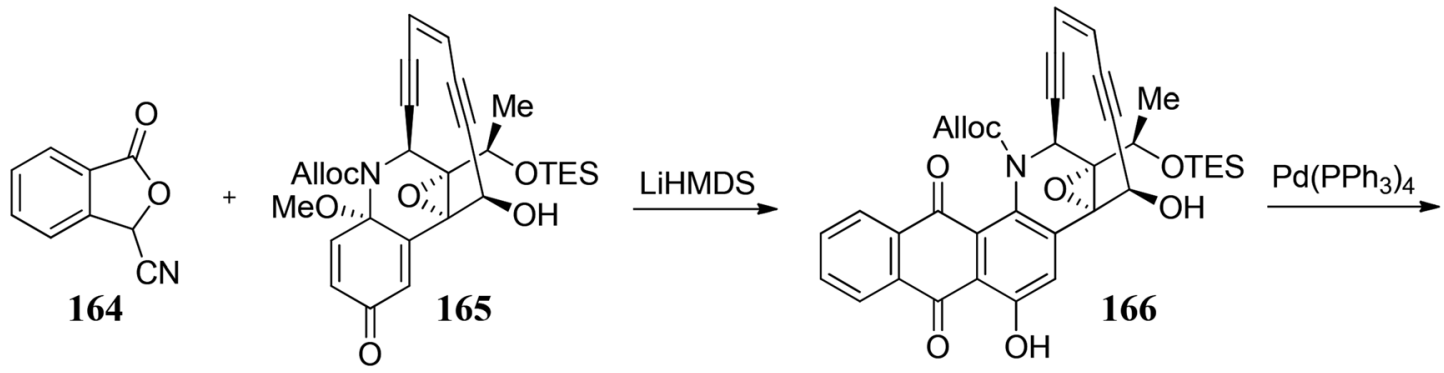

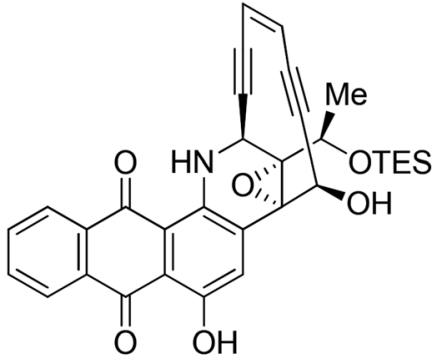

167

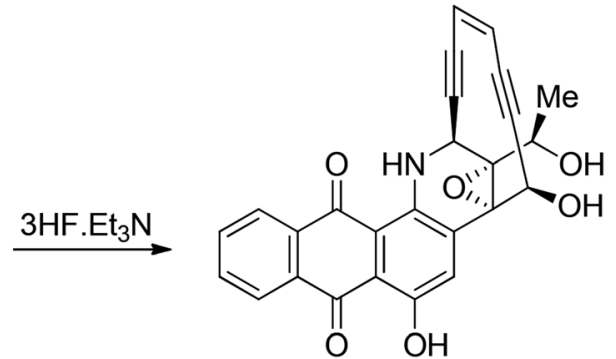

Uncialamycin

Scheme 32 Total synthesis of uncialamycin.

cancer cells in people with hereditary BRCA1 or BRCA2 mutations, which include some ovarian, breast, and prostate cancers. ${ }^{\mathbf{1 0 2}}$

Lou and co-workers ${ }^{\mathbf{1 0 3}}$ demonstrated an effective protocol for the synthesis of olaparib. The synthesis initiated by 3-phosphonophthalide 178, which on further reaction with aromatic aldehyde 179 gave 180, which further on reaction with hydrazine hydrate underwent ring expansion to give 181. 181 on amide coupling with 182 gave the desired drug, olaparib (Scheme 35).

\subsection{Synthesis of cytogenin (a bioactive natural product)}

Gadakh $^{\mathbf{1 0 4}}$ and co-workers developed a route for the synthesis of 3-carbethoxy-isocoumarins 184. The reagent system used in this 
<smiles>COc1cccc2c1C(=O)OC2C#N</smiles>

(2.2 equiv.)

168
(1)

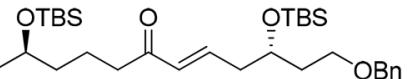

(1 equiv) 169

${ }^{t}$ BuOK (2.0 equiv.)

(2) $\mathrm{NaOH}$ (30 equiv.), $\mathrm{Me}_{2} \mathrm{SO}_{4}$ (40 equiv.) $49 \%$ overall yield

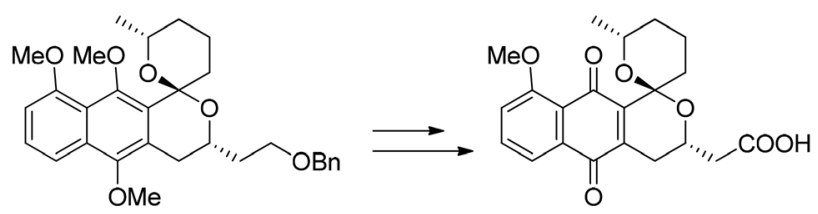

170
Griseusin B

(demonstrates variety of antibacterial and anticancer properties)

Scheme 33 Total synthesis of the griseusin B scaffold.

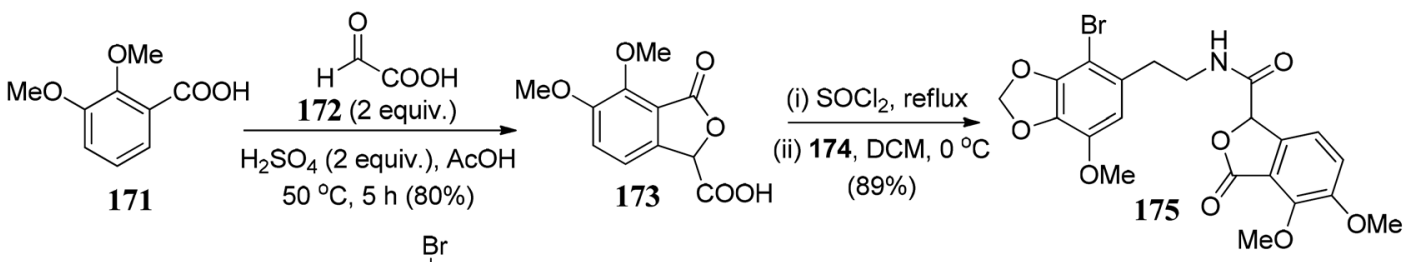

(i) $\mathrm{POCl}_{3}$, reflux (ii) $\mathrm{NaBH}_{4}, \mathrm{MeOH},-78^{\circ} \mathrm{C}$

(iii) $\mathrm{HCl}$, EtOAc $(52 \%)$<smiles>COc1ccc2c(c1OC)C(=O)O[C@H]2C1NCCc2c(Br)c3c(c(OC)c21)OCO3</smiles>

(i) $\mathrm{H}_{2}$, Raney Ni-W2, $\mathrm{Et}_{3} \mathrm{~N}, \mathrm{EtOH}$ reflux

(ii) recrystallization from $\mathrm{EtOH}$ (82\%)

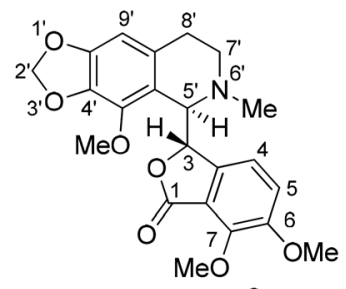

(i) $37 \% \mathrm{HCHO}, \mathrm{HCOOH}, 100^{\circ} \mathrm{C}$

(ii) aq. $\mathrm{HCl}$; aq. $\mathrm{NH}_{4} \mathrm{OH}$

(iii) recrystallization from EtOH

(75\%)

$( \pm)-\alpha$-noscapine 8

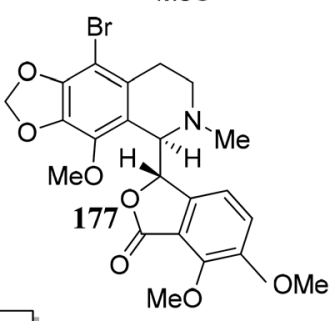

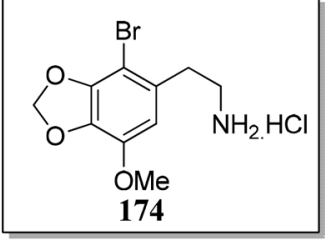

Scheme 34 Total synthesis of $( \pm)$ - $\alpha$-noscapine.<smiles>COP(=O)(OC)C1OC(=O)c2ccccc21</smiles>

178<smiles>N#Cc1cc(C=O)ccc1F</smiles>

Et

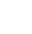<smiles>N#Cc1cc(/C=C2\OC(=O)c3ccccc32)ccc1F</smiles><smiles>N#C[C@H](O)[C@H](N)O</smiles><smiles>O=C(C1CC1)N1CCNCC1</smiles><smiles>O=C(c1cc(Cc2n[nH]c(=O)c3ccccc23)ccc1F)N1CCN(C(=O)C2CC2)CC1</smiles>

Olaparib

(FDA-approved targeted therapy for cancer)

Scheme 35 Synthesis of FDA approved the anti-cancer drug olaparib. 
<smiles>[R]c1cc2c(c([R])c1[R])C(=O)OC2C([R1])O</smiles>

183

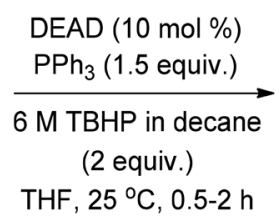

THF, $25^{\circ} \mathrm{C}, 0.5-2 \mathrm{~h}$

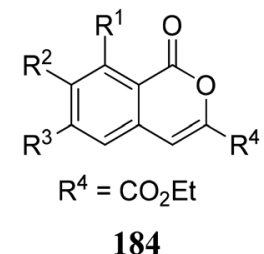

184
$R^{1}=R^{2}=R^{3}=H(94 \%)$

$\mathrm{R}^{1}=\mathrm{H}, \mathrm{R}^{2}=\mathrm{OMe}, \mathrm{R}^{3}=\mathrm{H}(96 \%)$

$R^{1}=R^{2}=O M e, R^{3}=H(92 \%)$

$\mathrm{R}^{1}=\mathrm{OMe}, \mathrm{R}^{2}=\mathrm{H}, \mathrm{R}^{3}=\mathrm{OMe}(92 \%)$

$R^{1}=R^{2}=R^{3}=$ OMe $(90 \%)$

$R^{1}=H, R^{2}=O B n, R^{3}=O M e(92 \%)$

$R^{1}=H, R^{2}=F, R^{3}=H(95 \%)$

$R^{1}=H, R^{2}=N_{2}, R^{3}=H(90 \%)$

Scheme 36 Intramolecular ring expansion of 3-substituted phthalides to isocoumarins.

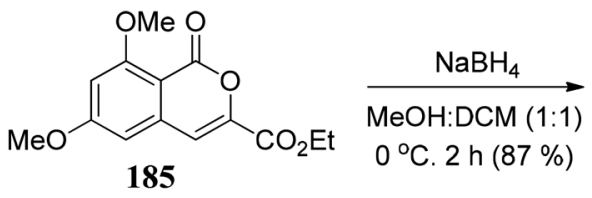<smiles>COc1cc(OC)c2c(=O)oc(CO)cc2c1</smiles>

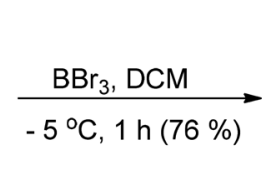

186

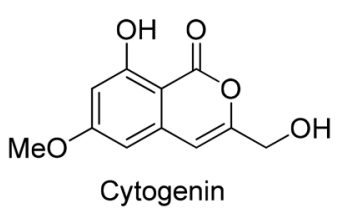

Cytogenin

Scheme 37 Synthesis of cytogenin'

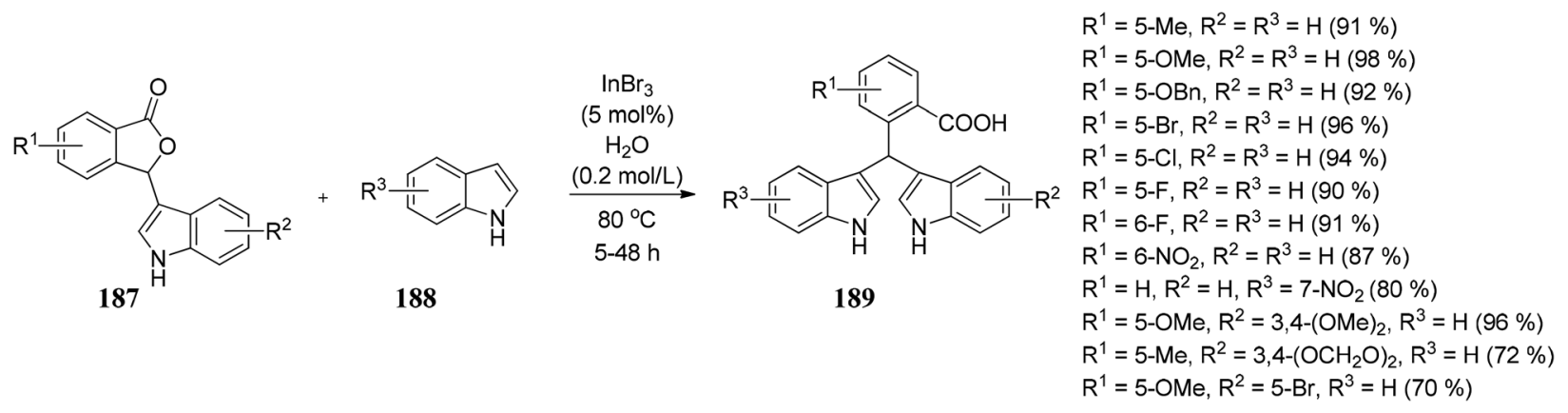

Scheme $38 \operatorname{lnBr}_{3}$ catalyzed Friedel-Crafts reaction between indole and 3-indolyl-substituted phthalides.

methodology is $\mathrm{DEAD} / \mathrm{PPh}_{3} / \mathrm{TBHP}$ through 1,2-shift intramolecular ring expansion, or we can say that the simple elimination is dependent on the various functional groups present on 3-substituted phthalides (Scheme 36).

The methodology is also used to synthesize cytogenin (a bioactive natural product) (Scheme 37).

\section{5 $\operatorname{InBr}_{3}$-catalyzed Friedel-Crafts reaction on 3-indolyl- substituted phthalides to develop unsymmetrical bis(indolyl) methanes (BIMs)}

Lin and co-workers ${ }^{105}$ developed a convenient, efficient, and novel synthetic route for synthesizing the unsymmetrical bis(indolyl)methanes (BIMs) 189 via InBr $_{3}$-catalyzed FriedelCrafts reaction by reacting indoles 188 with 3-indolylsubstituted phthalides 187 in water to obtain 189 in excellent yields (Scheme 38). These BIMs compounds present have excellent anti-Alzheimer's disease activity.

\section{Conclusions}

In the past decade, there has been considerable attention in the area of phthalides (more specifically 3-substituted phthalides) due to the development of various phthalides-based drugs. This has led to the development of elegant research methodologies with diverse applications in academic and industrial laboratories on micro- and macroscale operations. In light of the continued research in the area of 3-substituted phthalides, we have made an effort to present a critical review on the chemistry of 3-substituted phthalides. The chemistry of phthalides has been reviewed, but an independent and detailed review on the chemistry of 3-substituted phthalides is unavailable.

We have reviewed the isolation and biological activities of various 3 -substituted phthalides. We have presented pivotal research methodologies for the synthesis of racemic and chiral 3-substituted phthalides. These newer approaches are essential for the development of newer and elegant strategies for the synthesis of phthalide-based or similar molecular architecture with broader substrate scope and higher stereoselectivities. Also, we have reviewed the application of 3-substituted phthalides as a precursor for the synthesis of natural products and their analogs. Through this review, we have provided enough contextual information on the chemistry of 3-substituted phthalides, which can inspire organic chemists to develop methodologies for the synthesis of biologically and medicinally important molecules. 


\section{Conflicts of interest}

The authors declare no conflict of interest.

\section{Acknowledgements}

This work was supported by DST, and CSIR, New Delhi. A. A and G. R gratefully acknowledge DST-INSPIRE and Department of Chemistry, University of Delhi, Delhi, for their respective fellowships. M. S thanks UGC for the award of DSKPDF.

\section{References}

1 G. M. Cragg, D. J. Newman and K. M. Sander, J. Nat. Prod., 1997, 60, 52.

2 T. K. Devo and A. I. Scott, Handbook of Naturally Occurring Compounds, Elsevier, 1975.

3 (a) S. F. Brady, M. M. Wagenaar, M. Sing, J. E. Janso and J. Clardy, J. Org. Lett., 2000, 2, 404; (b) G. Lin, S. S. K. Chan, H. S. Chung and S. L. Li, Stud. Nat. Prod. Chem., 2005, 32, 611.

4 P. M. Hon, C. M. Lee, T. F. Choang, K. Y. Chui and H. N. C. Wong, Phytochemistry, 1990, 29, 1189.

5 R. Karmakar, P. Pahari and D. Mal, Chem. Rev., 2014, 114(12), 6213.

6 Risk Evaluation and Mitigation Strategy (REMS) Under Review for CellCept and Myfortic, U.S. Food and Drug Administration, retrieved 9th March 2019.

7 X. Diao, P. Deng, C. Xie, X. Li, D. Zhang, Y. Zhang and X. Chen, Drug Metab. Dispos., 2013, 41, 430.

8 (a) V. Snieckus, Chem. Rev., 1990, 90, 879; (b) D. Mal and P. Pahari, Chem. Rev., 2007, 107, 1892; (c) C. D. Donner, Tetrahedron, 2013, 69, 3747; (d) E. Hernández, J. M. Vélez and C. P. Vlaar, Tetrahedron Lett., 2007, 48, 8972; (e) K. Rathwell and M. A. Brimble, Synthesis, 2007, 5, 643; (f) A. S. Mitchell and R. A. Russell, Tetrahedron, 1995, 51, 5207.

9 K. Yoganathan, C. Rossant, S. Ng, Y. Huang, M. S. Butler and A. D. Buss, J. Nat. Prod., 2003, 66, 1116.

10 F. O. Shode, A. S. Mahomed and C. B. Rogers, Phytochemistry, 2002, 61, 955.

11 A. Arnone, G. Assante, G. Nasini and O. Vajna de Pava, Phytochemistry, 1990, 29, 613.

12 D. Wild, G. Toth and H. U. Humpf, J. Agric. Food Chem., 2002, 50, 3999.

13 (a) M. Singh and N. P. Argade, Org. Chem., 2010, 75, 3121; (b) D. Mal and P. Pahari, Chem. Rev., 2007, 107, 1892; (c) S. Natelson and A. Pearl, J. Am. Chem. Soc., 1936, 58, 2448.

14 W. Davies and W. H. Perkin, J. Chem. Soc., Trans., 1922, 121, 2202.

15 E. L. Eliel, A. W. Burgstahler, D. E. Rivard and L. Haefele, J. Am. Chem. Soc., 1955, 77, 5092.

16 M. Watanabe, M. Tsukazaki, Y. Hamada, M. Iwao and S. Furukawa, Chem. Pharm. Bull., 1989, 37, 2948.

17 V. Nair, R. R. Paul and E. Suresh, Synthesis, 2010, 21, 3741.

18 E. T. da Penha, J. A. Forni, A. F. P. Biajoli and C. R. D. Correia, Tetrahedron Lett., 2011, 52, 6342.

19 C. Len and B. Renoux, Targets Heterocycl. Syst., 2005, 9, 311.
20 (a) J. Taunton, J. L. Wood and S. L. Schreiber, J. Am. Chem. Soc., 1993, 115, 10378; (b) G. Sartori, F. Bigi, X. Tao, C. Porta, R. Maggi, G. Predieri, M. Lanfranchi and M. A. Pellinghelli, J. Org. Chem., 1995, 60, 6588; (c) M. L. Patil, H. B. Borate, D. E. Ponde, B. M. Bhawal and V. H. Deshpande, Tetrahedron Lett., 1999, 40, 4437; (d) M. L. Patil, H. B. Borate, D. E. Ponde and V. H. Deshpande, Tetrahedron, 2002, 58, 6615; (e) K. Knepper, R. E. Ziegert and S. T. Brase, Tetrahedron, 2004, 60, 8591; (f) V. Gonnot, S. Tisserand, M. Nicolas, R. Baati and C. Mioskowski, Tetrahedron Lett., 2007, 48, 7117; $(g)$ Z. Fei and F. E. McDonald, Org. Lett., 2007, 9, 3547.

21 For selected examples, see: (a) A. V. Karnik and S. S. Kamath, Synthesis, 2008, 12, 1832; (b) K. Tanaka, T. Osaka, K. Noguchi and M. Hirano, Org. Lett., 2007, 9, 1307; (c) R. Pedrosa, S. Sayaleroy and M. Vicente, Tetrahedron, 2006, 62, 10400; (d) M. Kosaka, S. Sekiguchi, J. Naito, M. Uemura, S. Kuwahara, M. Watanabe, N. Harada and K. Hiroi, Chirality, 2005, 17, 218; (e) B. Witulski and A. Zimmermann, Synlett, 2002, 11, 1855; (f) M. Takahashi, N. Sekine, T. Fujita, S. Watanabe, K. Yamaguchi and M. Sakamoto, J. Am. Chem. Soc., 1998, 120, 12770.

22 G. Lin, S. S. K. Chan, H. S. Chung and S. L. Li, Stud. Nat. Prod. Chem., 2005, 32, 611.

23 J. J. Beck and S. C. Chou, J. Nat. Prod., 2007, 70, 891.

24 S. Sasidharan, Y. Chen, D. Saravanan, K. M. Sundram and L. Y. Latha, Afr. J. Tradit., Complementary Altern. Med., 2011, 8, 1.

25 S. C. Lao, S. P. Li, K. K. W. Kan, P. Li, J. B. Wan, Y. T. Wang, T. T. X. Dong and K. W. K. Tsim, Anal. Chim. Acta, 2004, 526, 131.

26 P. Li, S. P. Li, S. C. Lao, C. M. Fu, K. K. W. Kan and Y. T. Wang, J. Pharm. Biomed. Anal., 2006, 40, 1073.

27 H. Mitsuhashi, U. Nagai, T. Muramatsu and H. Tashiro, Chem. Pharm. Bull., 1960, 8, 243.

28 Y. H. Li, S. L. Peng, Y. Zhou, K. B. Yu and L. S. Ding, Planta Med., 2006, 72, 652.

29 Y. Wei, W. Huang and Y. Gu, J. Chromatogr., 2013, 1284, 53. 30 R. Tomar, A. Sahni, I. Chandra, V. Tomar and R. Chandra, Mini-Rev. Org. Chem., 2018, 15, 345.

31 R. Figueroa, R. P. Hsung and C. C. Guevarra, Org. Lett., 2007, 9, 4857.

32 J. Li, L. Li, Y. Si, X. Jiang, L. Guo and Y. Che, Org. Lett., 2011, 13, 2670.

33 T. Ohzeki and K. Mori, Biosci., Biotechnol., Biochem., 2003, 67, 2584.

34 J. Fuska, D. Uhrin, B. Proksa, Z. Voticky and J. Ruppeldt, J. Antibiot., 1986, 39, 1605-1608.

35 J.-H. Huang and G. A. R. Johnston, Br. J. Pharmacol., 1990, 99, 727.

36 C. Puder, A. Zeeck and W. Beil, J. Antibiot., 2000, 53, 329.

37 K. Tianpanich, S. Prachya, S. Wiyakrutta, C. Mahidol, S. Ruchirawar and P. Kittakoop, J. Nat. Prod., 2011, 74, 79.

38 H. Inouye, T. Okuda, Y. Hirata, N. Nagakura and M. Yoshizaki, Chem. Pharm. Bull., 1967, 15, 786. 
39 A. Arnone, G. Assante, G. Nasini, S. Strada and A. Vercesi, J. Nat. Prod., 2002, 65, 48-50.

40 (a) R. Jadulco, G. Brauers, R. A. Edrada, R. Ebel, V. Wray, S. Sudarsono and P. Proksch, J. Nat. Prod., 2002, 65, 730; (b) U. Höller, J. B. Gloer and D. T. Wicklow, J. Nat. Prod., 2002, 65, 876.

41 H. Ishii, T. Ishikawa and J. Haginiwa, Yakugaku Zasshi, 1977, 97, 890.

42 (a) S. N. Yeola and R. S. Mali, ChemInform, 1987, 18, 639; (b) P. J. Choi, J. Sperry and M. A. Brimble, J. Org. Chem., 2010, 75, 7388.

43 F. Konno, T. Ishikawa, M. Kawahata and K. Yamaguchi, J. Org. Chem., 2009, 74, 9818.

44 D. J. Williams, Tetrahedron Lett., 1973, 14, 693.

45 (a) L. Rodriguez-Hahn, R. O'Reilly, B. Esquivel, E. Maldonado, A. Ortega, J. Cárdenas and R. A. Toscano, J. Org. Chem., 1990, 55, 3522; (b) G. Xu, L. Peng, X. Niu, Q. Zhao, R. Li and H. Sun, Helv. Chim. Acta, 2004, 87, 949.

46 W. M. Abdel Mageed, B. F. Milne, M. Wagner, M. Schumacher, P. Sandor, W. Pathom, M. Goodfellow, A. T. Bull, K. Horikoshi, R. Ebel, M. Diederich, H.-P. Fiedler and M. Jaspars, Org. Biomol. Chem., 2010, 8, 2352.

47 K. Liberra, R. Jansen and U. Lindequist, Pharmazie, 1998, 53, 578.

48 H. Mitsuhashi, T. Muramatsu, U. Nagai, T. Nakano and K. Ueno, Chem. Pharm. Bull., 1963, 11, 1317.

49 J. A. Palermo, M. V. R. Brasco, C. Pagnuolo and A. M. Seldes, J. Org. Chem., 2000, 65, 4482.

50 A. Arnone, G. Assante, G. Nasini and O. Vajna de Pava, Phytochemistry, 1990, 29, 613.

51 J. Liu, F. Li, E. L. Kim, J. L. Li, J. Hong, K. S. Bae, H. Y. Chung, H. S. Kim and J. H. Jung, J. Nat. Prod., 2011, 74, 1823.

52 G. Strobel, E. Ford, J. Worapong, J. K. Harper, A. M. Arif, D. M. Grant, P. C. W. Fung and R. M. W. Chau, Phytochemistry, 2002, 60, 179.

53 L. Xu, Z. He, J. Xue, X. Chen and X. Wei, J. Nat. Prod., 2010, 73, 885.

54 J. Kitajima, T. Ishikawa and M. Satoh, Phytochemistry, 2003, 64, 1003.

55 X. D. Qin, Z. J. Dong, J. K. Liu, L. M. Yang, R. R. Wang, Y. T. Zheng, Y. S. Wu and Q. T. Zheng, Helv. Chim. Acta, 2006, 89, 127.

56 D. Y. Kong, X. J. Liu, M. K. Teng and Z. H. Rao, Acta Pharmacol. Sin., 1985, 20, 747.

57 X. D. Qin, Z. J. Dong, J. K. Liu, L. M. Yang, R. R. Wang, T. T. Zheng, Y. Lu, Y. S. Wu and Q. T. Zheng, Helv. Chim. Acta, 2006, 89, 127.

58 F. Asari, T. Kusumi, G. Z. Zheng, Y. Z. Cen and H. Kakisawa, Chem. Lett., 1990, 19, 1885.

59 M. Tada and K. Chiba, Agric. Biol. Chem., 1984, 48, 1367.

60 F. O. Shde, A. S. Mahomed and C. Rogers, Phytochemistry, 2002, 61, 955.

61 M. Chinworrungsee, P. Kittakoop, M. Isaka, R. Chanphen, M. Tanticharoen and Y. Thebtaranonth, J. Chem. Soc., Perkin Trans. 1, 2002, 22, 2473.
62 K. Tianpanich, S. Prachya, S. Wiyakrutta, C. Mahidol, S. Ruchirawat and P. Kittakoop, J. Nat. Prod., 2011, 74, 79.

63 W. C. Tayone, M. Honma, S. Kanamaru, S. K. Tanaka, T. Nehira and M. Hashimoto, J. Nat. Prod., 2011, 74, 425.

64 J. Jeon, E. Julianti, H. Oha, W. Park, D. C. Oh, K. B. Oh and J. Shin, Tetrahedron Lett., 2013, 54, 3111.

65 A. Leon, R. A. Toscano, J. Tortoriello and G. Delgado, Nat. Prod. Res., 2011, 25, 1234.

66 P. Forgacs, J. Provost, A. Touche and A. Jehanno, J. Nat. Prod., 1986, 49, 178.

67 J. Fan, P.-M. Wang, J.-N. Wang, X. Zhao, Z.-W. Liu, J.-F. Wei and X.-Y. Shi, Sci. China: Chem., 2018, 61, 153.

68 T. V. Nguyen, W. J. Yoo and S. Kobayashi, Green Chem., 2017, 19, 2501.

69 A. Arcadi, G. Fabrizi, A. Goggiamani and F. Marinelli, J. Org. Chem., 2015, 80, 6986.

70 T. Matsuda, K. Suzuki, S. Abe, H. Kirikae and N. Okada, Tetrahedron, 2015, 71, 9264.

71 P. Gandeepan, P. Rajamalli and C. H. Cheng, Chem.-Eur. J., 2015, 21, 9198.

72 S.-i. Kawaguchi, K. Nakamura, K. Yamaguchi, Y. Sato, Y. Gonda, M. Nishioka, M. Sonoda, A. Nomoto and A. Ogawa, Eur. J. Org. Chem., 2017, 5343.

73 L. Jia and F. Han, J. Org. Chem., 2017, 13, 1425.

74 M. Perillo, A. Di Mola, R. Filosa, L. Palombi and A. Massa, RSC Adv., 2014, 4, 4239.

75 S. W. Youn, H. S. Song and J. H. Park, Org. Biomol. Chem., 2014, 12, 2388.

76 H. Tang, X. Zhang, A. Song and Z. Zhang, Mod. Res. Catal., 2012, 1, 11.

77 G. Li, D. Yin and X. T. Liang, Synth. Commun., 2004, 34, 1183.

78 J. Tatsugi, T. Hara and Y. Izawa, Chem. Lett., 1997, 26, 177.

79 H. Huang, Y. Wang, H. Zong and L. Song, Appl. Organomet. Chem., 2019, 33, e4643.

80 A. M. Carlos, R. Stieler and D. S. Lüdtke, Org. Biomol. Chem., 2019, 17, 283.

81 S. Kattela, E. C. de Lucca Jr and C. R. D. Correia, Chem.-Eur. J., 2018, 24, 17691.

82 Y. Ge, Z. Han, Z. Wang, C. G. Feng, Q. Zhao, G. Q. Lin and K. Ding, Angew. Chem., Int. Ed., 2018, 130, 13324.

83 B. Zhang, M. H. Xu and G. Q. Lin, Org. Lett., 2009, 11, 4712. 84 S. V. Kumbhar and C. Chen, RSC Adv., 2018, 8, 41355.

85 B. Lu, M. Zhao, G. Ding, X. Xie, L. Jiang, V. Ratovelomanana-Vidal and Z. G. Zhang, ChemCatChem, 2017, 9, 3989.

86 S. W. Youn, H. S. Song and J. H. Park, Org. Lett., 2014, 16, 1028.

87 Z. B. Zhang, Y. Q. Lu and X. F. Duan, Synthesis, 2011, 3435. 88 F. A. Davis and Y. W. Andemichael, J. Org. Chem., 1999, 64, 8627.

89 S. K. Ray, M. M. Sadhu, R. G. Biswas, R. A. Unhale and V. K. Singh, Org. Lett., 2019, 21, 417.

90 H. W. Moore, Science, 1977, 197, 527.

91 F. M. Hauser and R. P. Rhee, J. Org. Chem., 1978, 43, 178.

92 G. A. Kraus and H. Sugimoto, Tetrahedron Lett., 1978, 43, 2263. 
93 A. K. Chaturvedi and N. Rastogi, J. Org. Chem., 2016, 81, 3303.

94 Z. Zhuang, Z. P. Hu and W. W. Liao, Org. Lett., 2014, 16, 3380 .

95 S. Chakraborty, G. Das, S. Ghosh and D. Mal, Org. Biomol. Chem., 2016, 14, 10636.

96 K. C. Nicolaou, Y. Wang, M. Lu, D. Mandal, M. R. Pattanayak, R. Yu and L. Pasunoori, J. Am. Chem. Soc., 2016, 138, 8235.

97 B. J. Naysmith and M. A. Brimble, Org. Lett., 2013, 15, 2006. 98 V. Tomar, S. Kukreti, S. Prakash, J. Madan and R. Chandra, Curr. Top. Med. Chem., 2017, 17, 174.

99 (a) D. W. Empey, L. A. Laitinen, G. A. Young, C. E. Bye and D. T. D. Hughes, Eur. J. Clin. Pharmacol., 1979, 16, 393; (b) B. Dahlström, T. Mellstrand, C. G. Löfdahl and M. Johansson, Eur. J. Clin. Pharmacol., 1982, 22, 535.

100 (a) J. Zhou, D. Panda, J. W. Landen, L. Wilson and H. C. Joshi, J. Biol. Chem., 2002, 277, 39777; (b) Y. Ke,
K. Ye, H. E. Grossniklaus, D. R. Archer, H. C. Joshi and J. A. Kapp, Cancer Immunol. Immunother., 2000, 49, 217;

(c) J. W. Landen, R. Lang, S. J. McMahon, N. M. Rusan, A. M. Yvon, A. W. Adams and D. R. Archer, Cancer Res., 2002, 62, 4109; (d) J. W. Landen, V. Hau, M. Wang, T. Davis, B. Ciliax, B. H. Wainer and D. R. Archer, Cancer Res., 2004, 10, 5187.

101 J. Ni, H. Xiao, L. Weng, X. Wei and Y. Xu, Tetrahedron, 2011, 67, 5162.

102 P. C. Fong, D. S. Boss, T. A. Yap, A. Tutt, P. Wu, M. MerguiRoelvink and A. Ashworth, N. Engl. J. Med., 2009, 361, 123. 103 X.-y. Lou, X. Yang, Y.-l. Ding, J.-j. Wang, Q.-y. Yan, X.-g. Huang, Y.-h. Guo, X.-j. Wang and W.-s. Xiang, Chem. Res. Chin. Univ., 2013, 29, 231.

104 S. K. Gadakh and A. Sudalai, RSC Adv., 2014, 4, 57658.

105 H. Lin, Y. Zang, X. Sun and G. Lin, J. Chem., 2012, 30, 2309. 